\title{
Vasotocin and Mesotocin Stimulate the Biosynthesis of Neurosteroids in the Frog Brain
}

\author{
Jean-Luc Do-Rego, ${ }^{1}$ Sujata Acharjee, ${ }^{2}$ Jae Young Seong, ${ }^{3}$ Ludovic Galas, ${ }^{1}$ David Alexandre, ${ }^{1}$ Patrice Bizet, ${ }^{1}$ \\ Arlette Burlet, ${ }^{4}$ Hyuk Bang Kwon, ${ }^{2}$ Van Luu-The, ${ }^{5}$ Georges Pelletier, ${ }^{5}$ and Hubert Vaudry ${ }^{1}$ \\ ${ }^{1}$ Institut National de la Santé et de la Recherche Médicale, Unité 413, Laboratory of Cellular and Molecular Neuroendocrinology, European Institute for \\ Peptide Research, University of Rouen, 76821 Mont-Saint-Aignan, France, ${ }^{2}$ Hormone Research Center, Chonnam National University, Gwangju 500-757, \\ Korea, ${ }^{3}$ Graduate School of Medicine, Korea University College of Medicine, Seoul 136-705, Korea, ${ }^{4}$ Department of Cellular Biology, University of Nancy, \\ 54000 Nancy, France, and ${ }^{5}$ Laboratory of Molecular Endocrinology and Oncology, Laval University Hospital Center, Québec, Québec, Canada G1V 4G2
}

The neurohypophysial nonapeptides vasopressin (VP) and oxytocin (OT) modulate a broad range of cognitive and social activities. Notably, in amphibians, vasotocin (VT), the ortholog of mammalian VP, plays a crucial role in the control of sexual behaviors. Because several neurosteroids also regulate reproduction-related behaviors, we investigated the possible effect of VT and the OT ortholog mesotocin (MT) in the control of neurosteroid production. Double immunohistochemical labeling of frog brain sections revealed the presence of VT/MT-positive fibers in close proximity of neurons expressing the steroidogenic enzymes $3 \beta$-hydroxysteroid dehydrogenase $/ \Delta^{5}-\Delta^{4}$ isomerase $\left(3 \beta\right.$-HSD) and cytochrome P450 $17 \alpha$-hydroxylase/c17, 20-lyase $\left(\mathrm{P}_{450} \mathrm{Cl}_{17}\right)$. High concentrations of VT and MT receptor mRNAs were observed in diencephalic nuclei containing the $3 \beta$-HSD and $\mathrm{P}_{450_{\mathrm{C} 17}}$ neuronal populations. Exposure of frog hypothalamic explants to graded concentrations of VT or MT produced a dose-dependent increase in the formation of progesterone, 17hydroxypregnenolone, 17-hydroxyprogesterone, and dehydroepiandrosterone. The stimulatory effect of VT and MT on neurosteroid biosynthesis was mimicked by VP and $\mathrm{OT}$, as well as by a selective $\mathrm{V} 1 \mathrm{~b}$ receptor agonist, whereas $\mathrm{V} 2$ and $\mathrm{OT}$ receptor agonists had no effect. VT-induced neurosteroid production was completely suppressed by selective V1a receptor antagonists and was not affected by V2 and OT receptor antagonists. Concurrently, the effect of MT on neurosteroidogenesis was markedly attenuated by selective 0T and V1a receptor antagonists but not by a V2 antagonist. The present study provides the first evidence for a regulatory effect of VT and MT on neurosteroid biosynthesis. These data suggest that neurosteroids may mediate some of the behavioral actions of VT and MT.

Key words: neurosteroid biosynthesis; vasotocin; mesotocin; $3 \beta$-hydroxysteroid dehydrogenase/ $\Delta^{5}-\Delta^{4}$ isomerase; cytochrome P450 $17 \alpha$-hydroxylase/c17, 20-lyase; hypothalamus

\section{Introduction}

Brain neurons and/or glial cells have the capability of synthesizing bioactive steroids from cholesterol in very much the same as peripheral steroidogenic tissues (Robel and Baulieu, 1994; Mellon and Vaudry, 2001). These brain-born steroids, termed neurosteroids, regulate a number of behavioral and metabolic activities, such as response to novelty, aggressiveness, anxiety, depression, stress, learning and memory, sexual behavior, locomotion, body temperature, and blood pressure (Patchev et al., 1996; Baulieu et al., 1999; Rupprecht and Holsboer, 1999; Compagnone and Mellon, 2000; Vallée et al., 2000, 2001; Bernardi et

\footnotetext{
Received Oct. 19, 2005; revised April 25, 2006; accepted April 25, 2006.

This work was supported by grants from the Institut National de la Santé et de la Recherche Médicale (INSERM) Unité 413, a France-Québec exchange program (INSERM-Le Fonds de la Recherche en Santé de Québec; to G.P., H.V.), a France-Korean exchange program (INSERM-Korea Science and Engineering Foundation and Science and Technology Amicable Research; to J.Y.S., H.B.K., H.V.), the Plate-Forme Régionale de Recherche en Imagerie Cellulaire, and the Conseil Régional de Haute-Normandie. We thank Colette Piard for skillful technical assistance.

Correspondence should be addressed to Dr. Hubert Vaudry, European Institute for Peptide Research, Laboratory of Cellular and Molecular Neuroendocrinology, Institut National de la Santé et de la Recherche Médicale Unité 413, UA Centre National de la Recherche Scientifique, University of Rouen, 76821 Mont-Saint-Aignan, France. E-mail: hubert.vaudry@univ-rouen.fr.

D0I:10.1523/JNEUROSCI.4469-05.2006

Copyright $\odot 2006$ Society for Neuroscience $\quad$ 0270-6474/06/266749-12\$15.00/0
}

al., 2004). However, the neuronal mechanisms regulating the activity of neurosteroid-producing cells remain poorly understood.

The amphibian brain has proven to be a valuable model in which to investigate neurosteroid biosynthesis. First, several key enzymes have been localized in the frog CNS, including cytochrome $\mathrm{P} 450$ side-chain cleavage (P450scc) that catalyzes the conversion of cholesterol into pregnenolone $\left(\Delta^{5} \mathrm{P}\right)$ (Takase et al., 1999), 3 $\beta$-hydroxysteroid dehydrogenase/ $\Delta^{5}-\Delta^{4}$ isomerase $(3 \beta-\mathrm{HSD})$ that catalyzes the conversion of $\Delta^{5} \mathrm{P}$ into progesterone (P) (Mensah-Nyagan et al., 1994), $17 \beta$ hydroxysteroid dehydrogenase that catalyzes the conversion of androstenedione into testosterone (Mensah-Nyagan et al., 1996a,b), and hydroxysteroid sulfotransferase, which is responsible for the synthesis of biologically active sulfated steroids such as $\Delta^{5} \mathrm{P}$ sulfate ( $\left.\Delta^{5} \mathrm{PS}\right)$ and dehydroepiandrosterone sulfate (DHEAS) (Beaujean et al., 1999). Second, the rate of steroid biosynthesis in the frog brain is particularly high so that it is possible to study the mode of action of inhibitory neurotransmitters and neuropeptides on neurosteroid production. For instance, it has been shown that GABA, acting through $\mathrm{GABA}_{\mathrm{A}}$ receptors, inhibits the conversion of tritiated $\Delta^{5} \mathrm{P}\left(\left[{ }^{3} \mathrm{H}\right] \Delta{ }^{5} \mathrm{P}\right)$ into radioactive metabolites including $\mathrm{P}, 17$ - 
hydroxypregnenolone (17OH- $\left.\Delta^{5} \mathrm{P}\right), 17$-hydroxyprogesterone (17OH-P), and dehydroepiandrosterone (DHEA) (Do Rego et al., 2000) and that neuropeptide $Y$, acting through $Y 1$ receptors, inhibits the formation of $\Delta{ }^{5}$ PS and DHEAS (Beaujean et al., 2002).

In mammals, the neurohypophysial nonapeptides vasopressin (VP) and oxytocin (OT) exert a wide variety of behavioral effects, including modulation of learning and memory processes, social recognition, sexual behavior, anxiety, depression, stress responses, locomotion, and aggressiveness (Argiolas and Gessa, 1991; De Wied et al., 1993; De Wied, 1997; Everts and Koolhaas, 1997, 1999; Goodson and Bass, 2001; Hugin-Flores et al., 2003). In amphibians, vasotocin (VT), the ortholog of mammalian VP, plays a crucial role in the control of various reproductive behaviors, such as vocal communication (Boyd, 1997), appetitive responses to olfactory and visual stimuli (Iwata et al., 2000; Thompson and Moore, 2000), courtship behavior (Iwata et al., 2000), clasping behavior (Thompson and Moore, 2000, 2003), and egg-laying behavior (Moore et al., 2000). In amphibians as in mammals, the mechanism of action of neurohypophysial peptides in modulating these behaviors is still unclear. We have hypothesized that some of the central effects of VP/VT and OT/ mesotocin (MT) may be mediated through modulation of neurosteroid biosynthesis.

To test this hypothesis, (1) we searched whether neurosteroidproducing neurons are innervated by VT-/MT-positive fibers, (2) we studied the effect of VT and MT on $3 \beta$-HSD and P450 $17 \alpha$-hydroxylase/c17, 20-lyase ( $\left(\mathrm{P}^{4} 0_{\mathrm{C} 17}\right)$ activity, and (3) we characterized the pharmacological profile of the receptors involved in the action of VT and MT on neurosteroid biosynthesis in the frog hypothalamus.

\section{Materials and Methods}

Animals. Adult male frogs (Rana esculenta) of $\sim 30-40 \mathrm{~g}$ body weight were purchased from a commercial supplier (Couétard, Saint-Hilaire de Riez, France). The animals were housed in a temperature-controlled room $\left(8 \pm 0.5^{\circ} \mathrm{C}\right)$ under running water, on a $12 \mathrm{~h}$ light/dark schedule (lights on from 6:00 A.M. to 6:00 P.M.), for at least 1 week before use. To limit possible variations of neurosteroid biosynthesis attributable to circadian rhythms (Akwa et al., 1991), all animals were killed between 9:30 A.M. and 10:30 A.M. Animal manipulations were performed according to the recommendations of the French Ethical Committee and under the supervision of authorized investigators.

Chemicals and reagents. Synthetic peptides including MT, OT, VP, VT, the $\mathrm{V} 1$ receptor $(\mathrm{V} 1 \mathrm{R})$ agonist $\left(\left[\mathrm{Phe}^{2}, \mathrm{Orn}^{8}\right] \mathrm{OT}\right)$, the V1b receptor (V1bR) agonist ([deamino-Cys ${ }^{1}, \beta$-(3-pyridyl)-D-Ala $\left.\left.{ }^{2}, \operatorname{Arg}^{8}\right] \mathrm{VP}\right)$, the $\mathrm{V} 2$ receptor $(\mathrm{V} 2 \mathrm{R})$ agonist ([deamino-Cys $\left.\left.{ }^{1}, \mathrm{Val}^{4}, \mathrm{D}-\mathrm{Arg}^{8}\right] \mathrm{VP}\right)$, the V1a receptor (V1aR) antagonist $\left(\left[\mathrm{d}\left(\mathrm{CH}_{2}\right)_{5}{ }^{1}, \mathrm{Tyr}(\mathrm{Me})^{2}, \mathrm{Arg}^{8}\right] \mathrm{VP}\right)$, the V2R antagonist $\left(\left[\mathrm{d}\left(\mathrm{CH}_{2}\right)_{5}{ }^{1}, \mathrm{D}-\mathrm{Ile}^{2}, \mathrm{Ile}^{4}, \mathrm{Arg}^{8}\right] \mathrm{VP}\right)$, and the OT receptor (OTR) antagonist $\left(\left[\mathrm{d}\left(\mathrm{CH}_{2}\right)_{5}{ }^{1}, \operatorname{Tyr}(\mathrm{Me})^{2}, \mathrm{Thr}^{4}, \mathrm{Orn}^{8}\right.\right.$, des-Gly$\left.\mathrm{NH}_{2}{ }^{9}\right] \mathrm{VT}$ ) were purchased from Bachem (Bubendorf, Switzerland). The OTR agonist ([Thr $\left.\left.{ }^{4}, \mathrm{Gly}^{7}\right] \mathrm{OT}\right)$, and the VlaR antagonist ([Phe-acetyl ${ }^{1}$, O-Me-D-Tyr ${ }^{2}$, Arg $^{6,8}$, Lys $\left.^{9}\right]$ VP- $\left.\mathrm{NH}_{2}\right)$, synthetic androstenedione $\left(\Delta^{4}\right)$, androsterone (An), cortisol (F), DHEA, P, testosterone (T), 11deoxycortisol (S), 17OH-P, $17 \mathrm{OH}-\Delta{ }^{5} \mathrm{P}$, dihydrotestosterone, 3-aminobenzoic acid ethyl ester (MS222), aminoglutethimide, ketoconazole, propylene glycol, and HEPES were purchased from Sigma (St. Louis, MO). $\left[{ }^{3} \mathrm{H}\right] \Delta^{5} \mathrm{P}$ (specific activity, $21 \mathrm{Ci} / \mathrm{mmol}$ ) was obtained from PerkinElmer (Paris, France). Dichloromethane and methanol were from Carlo Erba (Val-de-Reuil, France). Bovine serum albumin (BSA) was from Boehringer Mannheim (Paris, France). Trilostane (WIN 24.540) was a gift from Winthrop Laboratories (Clichy, France).

Antibodies and oligonucleotides. Polyclonal antibodies raised in rabbit against human placental type I $3 \beta$-HSD (Luu-The et al., 1989) and against bovine testicular $\mathrm{P}_{450} \mathrm{C} 17$ (Tremblay et al., 1994) as well as a monoclonal antibody against VP (Robert et al., 1985) were used as pri- mary antibodies for immunohistochemistry. Alexa 594-conjugated goat anti-rabbit $\gamma$-globulins (GARs/Alexa 594) and Alexa 488-conjugated goat anti-mouse $\gamma$-globulins (GAMs/Alexa 488), both from Invitrogen (Carlsbad, CA), were used as secondary antibodies.

Oligonucleotides were designed from partial VT receptor (VTR) and MT receptor (MTR) cDNA sequences cloned previously in the frog $R$. esculenta (Acharjee et al., 2004) using the following primers: VTR forward, 5'-GGC ATG TTT GCG TCT ACC TAC-3'; VTR reverse, 5' -CAG ATG TGG TGC GTT TGG GAT-3'; MTR forward, 5'-GGG ATG TTT GCT TCT ACC TAC-3'; MTR reverse, 5' -CAG ATG TGG TCA GTC TGG GAC-3'.

Immunofluorescence procedure. Animals were anesthetized by immersion in $0.1 \% \mathrm{MS} 222$ buffered with $0.1 \mathrm{M} \mathrm{NaHCO}_{3}$ to $\mathrm{pH} 7.2$ and perfused transcardially with $50 \mathrm{ml}$ of $0.1 \mathrm{M}$ phosphate buffer (PB), $\mathrm{pH} 7.4$. The perfusion was performed with $50 \mathrm{ml}$ of Bouin's fixative. The brains were dissected and postfixed in the same fixative for $24 \mathrm{~h}$ at $4^{\circ} \mathrm{C}$. The tissues were rinsed overnight in $0.1 \mathrm{M} \mathrm{PB}$ containing $15 \%$ sucrose and then transferred into $0.1 \mathrm{~m} \mathrm{~PB}$ containing $30 \%$ sucrose for $24 \mathrm{~h}$. The brains were placed in an embedding medium (O.C.T. Tissue Tek; Leica, Nussloch, Germany), frozen at $-80^{\circ} \mathrm{C}$, cut in the frontal or sagittal plane in a cryomicrotome (6- $\mu$ m-thick sections), mounted on $0.5 \%$ gelatin $/ 5 \%$ chrome alun-coated slides, and kept at $4^{\circ} \mathrm{C}$ until use. The tissue sections were incubated overnight at $4^{\circ} \mathrm{C}$ in a humid atmosphere with a mixture containing the rabbit $3 \beta$-HSD antiserum (1:100) or $\mathrm{P} 450_{\mathrm{C} 17}$ antiserum $(1: 100)$ and the monoclonal VP antibody $(1: 1000)$ diluted in $0.1 \mathrm{M} \mathrm{PB}$ containing $0.3 \%$ Triton X-100 and $1 \%$ BSA. At the end of the incubation period, the sections were rinsed in three successive baths of $\mathrm{PB}$ and incubated for $90 \mathrm{~min}$ at room temperature with GAR/Alexa-594 and GAM/ Alexa-488 $(20 \mu \mathrm{g} / \mathrm{ml})$ each. Finally, the sections were rinsed in PB and mounted with $\mathrm{PB} /$ glycerol $(1: 1)$.

The preparations were examined using a filter-free confocal laser scanning microscope (CLSM TCS SP2 AOBS; Leica, Heidelberg, Germany) equipped with a fluorescence DM RXA2UV optical system, and an argon UV (excitation wavelength, $405 \mathrm{~nm}$ ), an argon (excitation wavelengths, $458,476,488$, and $514 \mathrm{~nm}$ ), and three helium-neon (excitation wavelengths, 543, 594, and $633 \mathrm{~nm}$ ) ion lasers (Leica). Dual-channel confocal laser scanning microscopic (CLSM) analysis was performed using a wavelength window $600 \leq \lambda \leq 650 \mathrm{~nm}$ for detection of Alexa-594 and a wavelength window $500 \leq \lambda \leq 550 \mathrm{~nm}$ for detection of Alexa-488.

To study the specificity of the immunoreaction, the following controls were performed: (1) substitution of the $3 \beta$-HSD or $\mathrm{P}^{4} 50_{\mathrm{C} 17}$ antiserum and the monoclonal VP antibody with PB; (2) incubation with nonimmune rabbit serum instead of the $3 \beta$-HSD or $\mathrm{P} 450_{\mathrm{C} 17}$ antiserum; and (3) preincubation of the $3 \beta$-HSD antiserum (diluted $1: 100$ ) with purified human placental type I $3 \beta$-HSD $\left(10^{-6} \mathrm{M}\right)$ and preincubation of the monoclonal VP antibody (diluted 1:1000) with graded concentrations of synthetic VT or MT $\left(10^{-10}\right.$ to $\left.10^{-5} \mathrm{M}\right)$. Neuroanatomical nomenclature was based on the atlas of Neary and Northcutt (1983).

In situ hybridization histochemistry. Adult male frogs were perfused transcardially as described above except that Bouin's fixative was replaced by $4 \%$ paraformaldehyde. Brain slices (12- $\mu \mathrm{m}$-thick) were cut in a cryomicrotome, mounted on $0.5 \%$ gelatin $/ 0.05 \%$ chrome alun $/ 0.01 \%$ poly-L-lysine-coated slides, and kept at $-80^{\circ} \mathrm{C}$ until use. The partial VTR and MTR cDNA sequences were subcloned into the pGEM-T vector between SpeI and NcoI sites, and sense and antisense riboprobes were generated by in vitro transcription using T7 and Sp6 RNA polymerases in the presence of $\left[{ }^{35} \mathrm{~S}\right] \mathrm{UTP}$ (Combination Systems; Promega, Madison, $\mathrm{WI}$ ). Sections were incubated for $10 \mathrm{~min}$ in $0.1 \mathrm{M}$ triethanolamine $/ 0.9 \%$ $\mathrm{NaCl}(\mathrm{pH} 8.0) / 0.25 \%$ acetic anhydride, rinsed in $2 \times \mathrm{SSC}$, and incubated for 60 min with prehybridization buffer, $\mathrm{pH} 7.5$, containing $50 \%$ formamide, $0.6 \mathrm{~m} \mathrm{NaCl}, 10 \mathrm{~mm}$ Tris- $\mathrm{HCl}$, $\mathrm{pH}$ 7.5, 0.02\% Ficoll, $0.02 \%$ polyvinylpyrrolidone, $0.02 \% \mathrm{BSA}, 1 \mathrm{~mm}$ ethylene-diaminetetra-acetic acid, $\mathrm{pH} 8.0,550 \mu \mathrm{g} / \mathrm{ml}$ denatured salmon sperm DNA, and $50 \mu \mathrm{g} / \mathrm{ml}$ yeast tRNA. Hybridization was performed overnight at $55^{\circ} \mathrm{C}$ in the same buffer (except for salmon sperm DNA, whose concentration was reduced to 60 $\mu \mathrm{g} / \mathrm{ml}$ ) supplemented with $10 \mathrm{~mm}$ dithiothreitol, $10 \%$ dextran sulfate, and $1.5 \times 10^{7} \mathrm{cpm} / \mathrm{ml}$ heat-denatured RNA riboprobes. Tissue sections were then washed in $2 \times \mathrm{SSC}$ at $55^{\circ} \mathrm{C}$ and treated with ribonuclease $\mathrm{A}(50$ $\mu \mathrm{g} / \mathrm{ml}$ ) for $60 \mathrm{~min}$ at $37^{\circ} \mathrm{C}$. Five high-stringency washes were performed 
in $0.01 \times$ SSC containing $14 \mathrm{~mm} \beta$-mercaptoethanol and $0.05 \%$ sodium pyrophosphate at $60^{\circ} \mathrm{C}$. Tissue sections were dehydrated in ethanol and exposed onto Biomax MR Film ( Eastman Kodak, Rochester, NY) for $15 \mathrm{~d}$. To identify anatomical structures, slices were stained with hematoxylin and eosin.

Measurement of $3 \beta-H S D$ and $\mathrm{P} 450_{\mathrm{Cl}}$ activities. Conversion of $\left[{ }^{3} \mathrm{H}\right] \Delta \Delta^{5} \mathrm{P}$ into different metabolites, including $\mathrm{P}, 17 \mathrm{OH}-\Delta^{5} \mathrm{P}, 17 \mathrm{OH}-\mathrm{P}$, and DHEA, was used as an index for the measurement of $3 \beta$-HSD and $\mathrm{P}_{450} \mathrm{C} 17_{7}$ activities, as described previously (Mensah-Nyagan et al., 1994). Briefly, for each experiment, the hypothalami of four frogs were rapidly dissected and each hypothalamus was cut into two slices. The tissue fragments were preincubated for $15 \mathrm{~min}$ in $1 \mathrm{ml}$ of Ringer's solution consisting of $15 \mathrm{~mm}$ HEPES buffer, $112 \mathrm{~mm} \mathrm{NaCl}, 15 \mathrm{~mm} \mathrm{NaHCO}_{3}, 2 \mathrm{~mm}$ $\mathrm{CaCl}_{2}$, and $2 \mathrm{~mm} \mathrm{KCl}$, supplemented with $2 \mathrm{mg}$ glucose $/ \mathrm{ml}$ and $0.3 \mathrm{mg}$ $\mathrm{BSA} / \mathrm{ml}$. The incubation medium was gassed with a $95 \% \mathrm{O}_{2} / 5 \% \mathrm{CO}_{2}$ mixture, and the $\mathrm{pH}$ was adjusted to 7.4. The hypothalamic fragments were incubated at $24^{\circ} \mathrm{C}$ for $2 \mathrm{~h}(0.5-4 \mathrm{~h}$ for time course experiments) in $500 \mu \mathrm{l}$ of Ringer's medium containing $10^{-6} \mathrm{M}\left[{ }^{3} \mathrm{H}\right] \Delta^{5} \mathrm{P}$ and $4 \%$ propylene glycol, in the absence or presence of test substances. Aminoglutethimide and ketoconazole, which are poorly soluble in water, were dissolved in methanol $(0.1 \%)$ and acetone $(0.1 \%)$, respectively, and the same concentration of organic solvent was added in the control samples. At the end of the incubation period, the tissues were rinsed four times with ice-cold Ringer's buffer, and the reaction was stopped by adding 1 $\mathrm{ml}$ of trichloroacetic acid. The tissues were homogenized using a glass Potter homogenizer, and the steroids were extracted three times by $1 \mathrm{ml}$ of dichloromethane. The organic phase containing the steroids was evaporated under nitrogen, and the extract was redissolved in a solution consisting of $65 \%$ water/trifluoroacetic acid (TFA) (99.9:0.1; v/v; solution A) and 35\% methanol/water/TFA (90:9.98:0.02; v/v/v; solution B) and prepurified on Sep-Pak $\mathrm{C}_{18}$ cartridges (Waters Associates, Milford, MA) equilibrated with a solution made of $65 \%$ solution A and $35 \%$ solution B. Steroids were eluted with $4 \mathrm{ml}$ of a solution made of $10 \%$ solution A and $90 \%$ solution B. The solvent was evaporated in a SpeedVac concentrator (Savant, Hicksville, NY), and the extracts were kept dry at $4^{\circ} \mathrm{C}$ until analysis.

HPLC analysis. Sep-Pak-prepurified extracts were analyzed by reversed-phase HPLC. The HPLC equipment consisted of a Gilson (Villier-le-Bel, France) model 305 master pump acting as a system controller, a Gilson model 306 slave pump controlled by the previous pump, a Gilson model 115 variable wavelength UV detector set at $240 \mathrm{~nm}$, and a Rheodyne (Rohnert Park, CA) model 7125 injector. A $0.39 \times 30 \mathrm{~cm}$ Nova-Pak $\mathrm{C}_{18}$ column (Waters Associates) equilibrated with $60 \%$ solution $A$ and $40 \%$ solution $B$ was used for analysis. Each extract was injected at a flow rate of $1 \mathrm{ml} / \mathrm{min}$ and separated using a gradient of solution $\mathrm{B}$ ( $40-100 \%$ over $104 \mathrm{~min})$, including four isocratic steps at $40 \%(0-10$ $\mathrm{min}$ ), 64\% (39-59 $\mathrm{min}), 80 \%$ (69-79 $\mathrm{min}$ ), and 100\% (94-104 min) solution B. Tritiated compounds eluted from the HPLC column were detected by using a flow scintillation analyzer (Radiomatic Flo-one/Beta A-500; Packard, Meridien, CT) equipped with a Pentium III personal computer that automatically integrated the peak surface and calculated the percentage of total radioactivity contained in each peak.

Synthetic steroids used as reference standards were chromatographed under the same conditions as the tissue extracts and detected by UV absorption.

Quantification of steroid biosynthesis and statistical analysis. The amounts of radioactive steroids formed by conversion of $\left[{ }^{3} \mathrm{H}\right] \Delta^{5} \mathrm{P}$ were expressed as a percentage of the total radioactivity contained in all peaks resolved by HPLC, including $\left[{ }^{3} \mathrm{H}\right] \Delta{ }^{5} \mathrm{P}$ itself. Each value is the mean of four independent experiments. Statistical analysis was performed by ANOVA, followed by a Dunnett's or a Bonferroni's multiple comparison test.

\section{Results}

\section{Immunocytochemistry}

Labeling of frog brain slices with each primary antibody revealed that most of the nuclei that contain $3 \beta$-HSD- and/or $\mathrm{P} 450_{\mathrm{C} 17^{-}}$ immunoreactive neurons are also innervated by VT- and/or MTcontaining fibers, i.e., the anterior commissure, the lateral and medial amygdala, the anterior preoptic area, the dorsal and ventral hypothalamic nuclei, the suprachiasmatic nucleus, the posterior tuberculum, the nucleus of the periventricular organ, and the ventral part of the magnocellular preoptic nucleus (Table 1).

Double labeling of frog diencephalic slices with the rabbit $3 \beta$-HSD antiserum and the monoclonal VP antibody, combined with dual-channel CLSM analysis, showed that many $3 \beta$-HSDpositive cell bodies are surrounded by bundles of beaded fibers containing VP-like immunoreactivity in the anterior preoptic area (Fig. $1 A-C$ ) and the posterior tuberculum (Fig. $1 D-F$ ). At a higher magnification, VP-immunoreactive fibers appeared to contact $3 \beta$-HSD-containing neurons (Fig. 1, insets). Similarly, in the dorsal and ventral hypothalamic nuclei, the nucleus of the periventricular organ, and the suprachiasmatic nucleus, $3 \beta$ HSD-positive perikarya were surrounded by a network of VPimmunoreactive processes (data not shown). Double labeling of brain sections with the rabbit $\mathrm{P} 40_{\mathrm{C} 17}$ antiserum and the monoclonal VP antibody revealed the existence of varicose VPimmunoreactive processes next to $\mathrm{P} 450_{\mathrm{C} 17}$-positive cell bodies in the anterior preoptic area (Fig. $2 A-C$ ) and in the medial amygdala (Fig. $2 D-F$ ). At a higher magnification, VP-immunoreactive fibers were seen in the close vicinity of $\mathrm{P}_{450_{\mathrm{C} 17}}$-positive cells (Fig. 2 , insets). $\mathrm{P} 450_{\mathrm{C} 17}$-positive neurons surrounded by VPimmunoreactive nerve fibers were also observed in the lateral amygdala, the ventral part of the magnocellular preoptic nucleus, the nucleus of the periventricular organ, the posterior tuberculum, and the dorsal and ventral hypothalamic nuclei (data not shown).

Preincubation of the $3 \beta$-HSD antiserum with purified human type I $3 \beta$-HSD $\left(10^{-6} \mathrm{M}\right.$ ) totally abolished immunostaining (data not shown). Similarly, preincubation of the monoclonal VP antibody with graded concentrations of synthetic VT and MT $\left(10^{-10}\right.$ to $\left.10^{-5} \mathrm{M}\right)$ resulted in a dose-dependent decrease of the immunoreaction, with total extinction at concentrations of $10^{-7}$ $\mathrm{M} \mathrm{VT}$ and $10^{-5} \mathrm{M} \mathrm{MT} \mathrm{(Table} \mathrm{2,} \mathrm{Fig.} \mathrm{3).} \mathrm{No} \mathrm{fluorescence} \mathrm{was}$ observed when the primary antisera against $3 \beta$-HSD or $\mathrm{P}_{450} 0_{\mathrm{C} 17}$ were substituted with nonimmune rabbit serum or when the VP antibody was substituted with PB (data not shown).

\section{Distribution of VT and MT receptors in the diencephalon}

The localization of VTR and MTR mRNAs in the frog diencephalon was determined by in situ hybridization histochemistry (Fig. 4). A high concentration of VTR mRNA was observed in the anterior preoptic area and the lateral amygdala (Fig. $4 \mathrm{~A}$ ), as well as in the posterior tuberculum, the nucleus of the periventricular organ, the posterior thalamic nucleus, and the dorsal and ventral hypothalamic nuclei (Fig. $4 B$ ). A moderate density of VTR mRNA was detected in the pallium and the medial amygdala (Fig. $4 A$ ).

A high concentration of MTR mRNA was found in all subdivisions of the pallium, the anterior commissure, the lateral and medial amygdala, the anterior preoptic area (Fig. $4 D$ ), the posterior thalamic nucleus, the posterior tuberculum, the nucleus of the periventricular organ, and the dorsal and ventral hypothalamic nuclei (Fig. 4E). A moderate density of MTR mRNA was seen in the anterior commissure, the dorsal pallium, the lateral septum, the nucleus accumbens (Fig. 4D), the central thalamic nucleus, and the ventromedial, dorsal, and ventral thalamic nuclei (Fig. 4E). Control sections incubated with the sense VTR (Fig. 4C) and MTR (Fig. 4F) probes exhibited only weak background staining.

A comparison of the distribution and relative density of VTR and MTR mRNAs to those of $3 \beta$-HSD-immunoreactive neurons described previously (Mensah-Nyagan et al., 1994) and $\mathrm{P}_{450}{\mathrm{C} 17^{-}}^{-}$ 
Table 1. Comparative distribution and relative abundance of $3 \beta$-HSD- and $\mathrm{P} 450_{\mathrm{C17}}$-positive neurons, VT- and MT-immunoreactive fibers, and VTR and MTR $\mathrm{mRNAs}$ in the telencephalon and diencephalon of the frog R. esculenta

\begin{tabular}{|c|c|c|c|c|c|c|}
\hline Structures $^{a}$ & $3 \beta$-HSD ${ }^{b}$ cells & ${\mathrm{P} 450_{\mathrm{C} 17}{ }^{\mathrm{C}} \text { cells }}$ & $\mathrm{VT}^{d}$ fibers & $\mathrm{MT}^{d}$ fibers & VTR mRNA & MTR mRNA \\
\hline \multicolumn{7}{|l|}{ Telencephalon } \\
\hline Accessory olfactory bulb (AOB) & - & - & - & - & - & - \\
\hline Anterior commissure (AC) & - & + & + & ++ & - & ++ \\
\hline Anterior entopeduncular nucleus (Ea) & - & - & + & + & + & + \\
\hline Bed nucleus of the pallial commissiure (BN) & - & + & - & - & - & + \\
\hline Dorsal pallium (DP) & - & + & - & - & ++ & +++ \\
\hline Dorsal striatum (DS) & - & - & + & + & ++ & ++ \\
\hline Lateral amygdala (LA) & - & ++ & + & + & +++ & +++ \\
\hline Lateral pallium (LP) & - & + & + & + & +++ & +++ \\
\hline Lateral septum (LS) & - & - & +++ & ++ & ++ & ++ \\
\hline Medial amygdala (MA) & - & + & +++ & ++ & + & +++ \\
\hline Medial pallium (MP) & - & + & - & ++ & ++ & +++ \\
\hline Medial septum (MS) & - & - & + & + & + & + \\
\hline Nucleus accumbens (NA) & - & - & + & + & + & +++ \\
\hline Olfactory bulb, extragranular plexiform layer (EPL) & - & - & + & + & - & - \\
\hline Olfactory bulb, glomerular layer (GL) & - & - & - & - & - & - \\
\hline Olfactory bulb, internal granular layer (IGL) & - & + & + & + & + & + \\
\hline Olfactory bulb, mitral cellular layer (ML) & - & ++ & - & - & - & - \\
\hline Olfactory tubercle (T0) & - & - & + & + & + & - \\
\hline Postolfactory eminence (PE) & - & - & - & + & - & - \\
\hline Ventral striatum (VS) & - & - & - & + & +++ & +++ \\
\hline \multicolumn{7}{|l|}{ Diencephalon } \\
\hline Anterior preoptic area (Poa) & +++ & +++ & +++ & +++ & +++ & +++ \\
\hline Anterior thalamic nucleus (A) & - & - & - & - & + & + \\
\hline Bed nucleus of the stria medullaris (BM) & - & - & - & - & - & - \\
\hline Central thalamic nucleus (CNT) & - & - & + & + & ++ & ++ \\
\hline Corpus geniculatum thalamicum (CP) & - & - & - & - & - & - \\
\hline Dorsal hypothalamic nucleus (DH) & ++ & + & ++ & + & +++ & ++ \\
\hline Habenular commissure (Hc) & - & - & - & - & - & - \\
\hline Dorsal habenular nucleus (Hd) & - & +++ & - & - & ++ & - \\
\hline Epiphysis (E) & - & - & - & - & - & - \\
\hline Lateral thalamic nucleus, anterior division (La) & - & - & + & + & - & + \\
\hline Lateral hypothalamic nucleus (LH) & - & - & +++ & ++ & - & - \\
\hline Lateral thalamic nucleus, posterodorsal division (Lpd) & - & - & - & - & - & - \\
\hline Lateral thalamic nucleus, posteroventral division (Lpv) & - & - & - & - & - & - \\
\hline Magnocellular preoptic nucleus (Mg) & - & + & +++ & +++ & + & + \\
\hline Magnocellular preoptic nucleus, dorsal part (Mgd) & - & + & ++ & ++ & +++ & + \\
\hline Magnocellular preoptic nucleus, ventral part (Mgv) & - & ++ & +++ & +++ & +++ & ++ \\
\hline Neuropil of Bellonci (B) & - & - & - & - & - & - \\
\hline Nucleus of Bellonci (NB) & - & - & - & - & - & - \\
\hline Nucleus of the periventricular organ (NPv) & ++ & ++ & ++ & + & +++ & +++ \\
\hline Optic chiasma (OC) & - & - & - & - & - & - \\
\hline Optic nerve (ON) & - & - & - & - & - & - \\
\hline Organum vasculosum (OV) & - & - & - & - & - & - \\
\hline Posterior entopeduncular nucleus (Ep) & - & - & - & - & - & - \\
\hline Posterior thalamic nucleus (P) & - & - & + & + & ++ & +++ \\
\hline Posterior tuberculum (TP) & ++ & ++ & ++ & +++ & +++ & +++ \\
\hline Subcommissural organ (CO) & - & - & + & + & - & - \\
\hline Superficial ventral thalamic nucleus (Vs) & - & - & - & - & - & - \\
\hline Suprachiasmatic nucleus (SC) & + & + & +++ & +++ & ++ & ++ \\
\hline Thalamic eminence (TE) & - & - & + & + & - & + \\
\hline Uncinate neuropil (U) & - & - & + & + & - & - \\
\hline Ventral habenular nucleus (Hv) & - & + & ++ & ++ & ++ & - \\
\hline Ventral hypothalamic nucleus (VH) & ++ & +++ & +++ & ++ & +++ & ++ \\
\hline Ventrolateral thalamic nucleus, dorsal part (VId) & - & - & - & - & + & - \\
\hline Ventrolateral thalamic nucleus, ventral part (Vlv) & - & - & - & - & + & - \\
\hline Ventromedial thalamic nucleus (VM) & - & + & + & + & +++ & ++ \\
\hline
\end{tabular}

The following scale was used: +++ , high density; ++ , moderate density; + , low density; - , no immunoreactive cell bodies or fibers or no mRNA hybridization signal. ${ }^{a}$ Abbreviations according to Neary and Northcutt (1983).

${ }^{b}$ Distribution of $3 \beta$-HSD-immunoreactive cells in the telencephalon and diencephalon of $R$. esculenta according to Mensah-Nyagan et al. (1994).

'Distribution of $\mathrm{P}^{2} \mathrm{CO}_{\mathrm{C} 17}$-immunoreactive cells in the telencephalon and diencephalon of $R$. esculenta (our unpublished data).

${ }^{d}$ Distribution of VT- and MT-immunoreactive fibers in the telencephalon and diencephalon of the frog R. esculenta (R. perezi) according to González and Smeets (1992) and Smeets and González (2001). 

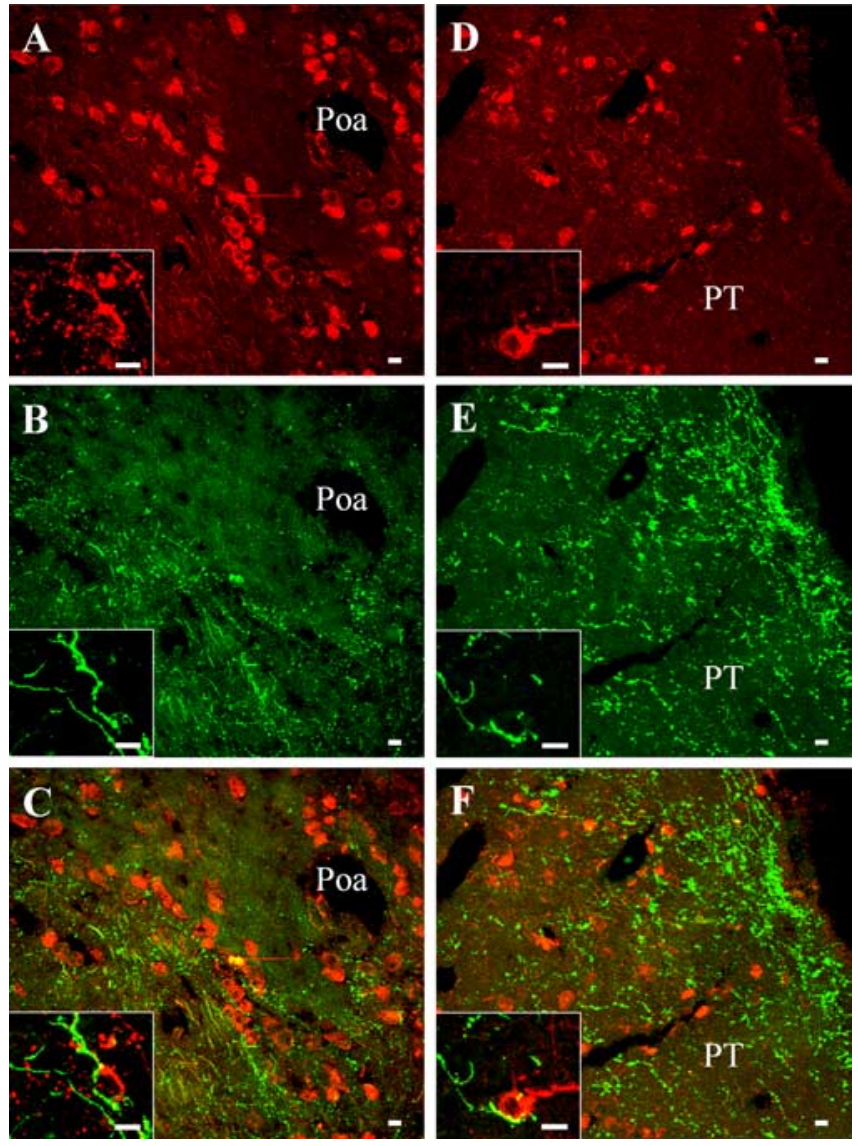

Figure 1. Dual-channel confocal laser scanning microscope photomicrographs comparing the distribution of $3 \beta$-HSD- and VP-like immunoreactivity in the anterior preoptic area (Poa; $\boldsymbol{A}-\boldsymbol{C})$ and in the posterior tuberculum (PT; $\boldsymbol{D}-\boldsymbol{F})$. Frontal brain sections were labeled with the rabbit antiserum against $3 \beta$-HSD revealed with GAR/Alexa-594 $(\boldsymbol{A}, \boldsymbol{D})$ and the monoclonal antibody against VP revealed with GAM/Alexa-488 $(\boldsymbol{B}, \boldsymbol{E})$. Combination of the two images acquired in $\boldsymbol{A}$ and $\boldsymbol{B}$ and in $\boldsymbol{D}$ and $\boldsymbol{E}$ revealed that the $3 \beta$-HSD-positive cells in the anterior preoptic area and the posterior tuberculum are contacted by VT-immunoreactive fibers $(\boldsymbol{C}, \boldsymbol{F})$. The insets show higher-magnification views of VT-immunoreactive nerve fibers in the close vicinity of $3 \beta$-HSD-positive neurons $(\boldsymbol{C}, \boldsymbol{F})$. Scale bars, $10 \mu \mathrm{m}$.

containing neurons (our unpublished data) in the frog telencephalon and diencephalon revealed that most nuclei that contain $3 \beta$-HSD- and $\mathrm{P} 450_{\mathrm{C} 17}$-positive neurons are enriched with VTR and MTR mRNAs, notably the anterior preoptic area, the lateral and medial amygdala, the posterior tuberculum, the nucleus of the periventricular organ, and the dorsal and ventral hypothalamic nuclei (Table 1, Fig. 4). In contrast, $3 \beta$-HSD- and $\mathrm{P} 450_{\mathrm{C} 17}$-immunoreactive cell bodies were not found in several telencephalic and diencephalic nuclei in which VTR and MTR mRNAs are located, such as the dorsal and ventral striatum, the lateral septum, the nucleus accumbens, and the central, posterior, and ventral thalamic nuclei (Table 1).

\section{Effects of VT and MT on neurosteroid biosynthesis}

After a $2 \mathrm{~h}$ incubation of frog hypothalamic explants with $\left[{ }^{3} \mathrm{H}\right] \Delta{ }^{5} \mathrm{P}$, reversed-phase HPLC analysis of the tissue extracts made it possible to resolve several radioactive compounds, including $17 \mathrm{OH}-\Delta^{5} \mathrm{P}, \mathrm{An}, \mathrm{DHEA}, \Delta^{4}, \mathrm{~T}, 17 \mathrm{OH}-\mathrm{P}$, and $\mathrm{P}$ (Fig. $5 A$ ). Addition of VT $\left(10^{-7} \mathrm{M}\right)$ to the incubation medium markedly stimulated the conversion of $\left[{ }^{3} \mathrm{H}\right] \Delta{ }^{5} \mathrm{P}$ into radioactive steroids (Fig. $5 B$ ). Exposure of frog hypothalamic explants to graded concentrations of VT or MT $\left(10^{-10}\right.$ to $\left.10^{-5} \mathrm{M}\right)$ induced a dose-
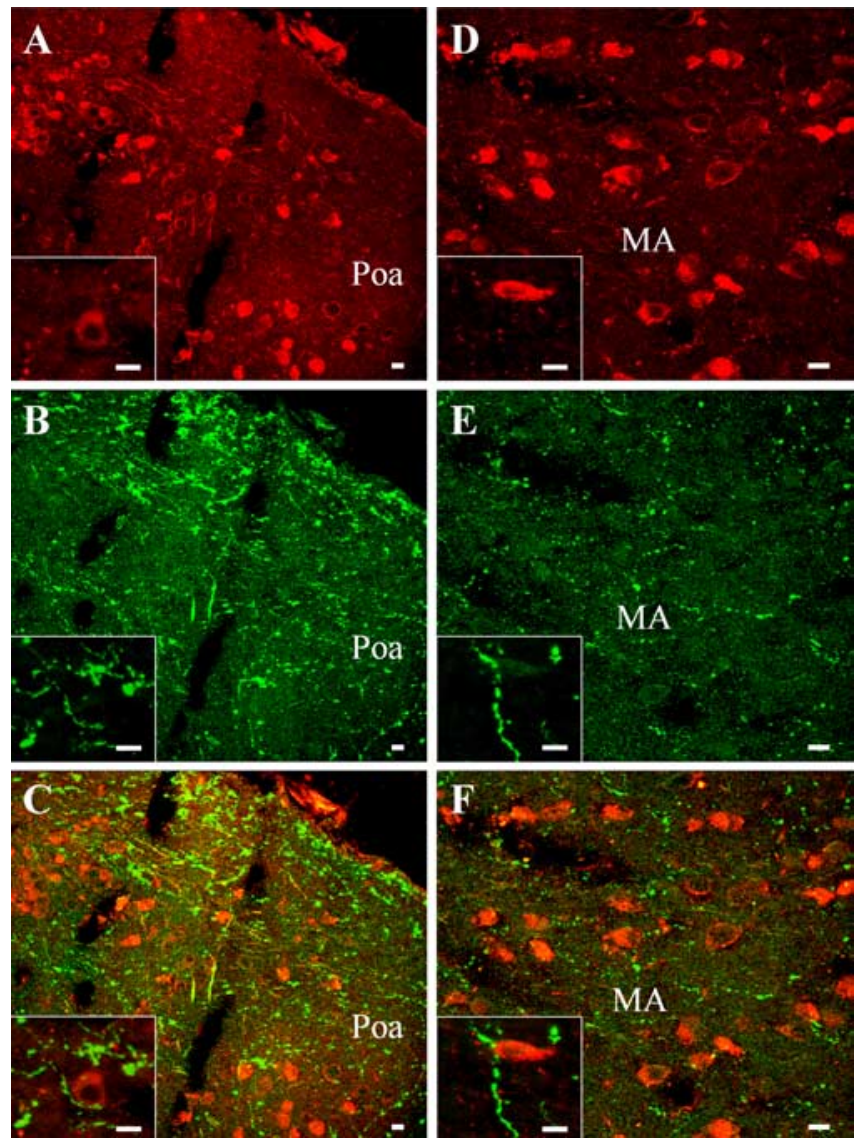

Figure 2. Dual-channel confocal laser scanning microscope photomicrographs comparing the distribution of $\mathrm{P} 4 \mathrm{CO}_{\mathrm{C} 7}$ - and VP-like immunoreactivity in the anterior preoptic area (Poa; $\boldsymbol{A}-\boldsymbol{C}$ ) and in the medial amygdala (MA; $\boldsymbol{D}-\boldsymbol{F})$. Frontal brain sections were labeled with the rabbit antiserum against $\mathrm{P}^{450_{C 17}}$ revealed with $\mathrm{GAR} /$ Alexa-594 $(\boldsymbol{A}, \boldsymbol{D})$ and the monoclonal antibody against VP revealed with GAM/Alexa-488 $(\boldsymbol{B}, \boldsymbol{E})$. Combination of the two images acquired in $\boldsymbol{A}$ and $\boldsymbol{B}$ and in $\boldsymbol{D}$ and $\boldsymbol{E}$ revealed that the $\mathrm{P}^{450_{\mathrm{C} 17}}$-positive cells in the anterior preoptic area and the medial amygdala are contacted by VT-immunoreactive fibers $(\boldsymbol{C}, \boldsymbol{F})$. The insets show higher-magnification views of VT-immunoreactive nerve fibers in the close vicinity of $\mathrm{P}^{450_{\mathrm{C} 17}}$-positive neurons $(\boldsymbol{C}, \boldsymbol{F})$. Scale bars, $10 \mu \mathrm{m}$.

dependent increase of $\mathrm{P}, 17 \mathrm{OH}-\Delta^{5} \mathrm{P}, 17 \mathrm{OH}-\mathrm{P}$, and DHEA biosynthesis (Fig. 6). Maximum stimulation was observed at a concentration of $10^{-6} \mathrm{M}$. Administration of graded concentrations of the mammalian nonapeptides VP and OT also provoked a dose-dependent stimulation of $\mathrm{P}, 17 \mathrm{OH}-\Delta^{5} \mathrm{P}, 17 \mathrm{OH}-\mathrm{P}$, and DHEA production (Fig. 6).

Time course experiments revealed that VT and MT induced a significant stimulation of neurosteroid biosynthesis within 30 min and the maximum response was observed after $2 \mathrm{~h}$; then, the stimulatory effect of VT and MT gradually declined during the next 2 h (Fig. 7).

Exposure of frog hypothalamic explants to aminoglutethimide $\left(10^{-4} \mathrm{M}\right)$, a selective inhibitor of cytochrome P450scc, did not significantly affect the spontaneous conversion of $\Delta^{5} \mathrm{P}$ into $\mathrm{P}$ and $17 \mathrm{OH}-\Delta^{5} \mathrm{P}$ (Fig. 8). Aminoglutethimide did not significantly modify the effect of VT and MT on $17 \mathrm{OH}-\Delta^{5} \mathrm{P}$ production but significantly $(p<0.01)$ enhanced the stimulatory effect of VT and MT on P formation (Fig. 8). Incubation of frog hypothalamic slices with trilostane $\left(10^{-4} \mathrm{M}\right)$, a specific inhibitor of $3 \beta-\mathrm{HSD}$, and ketoconazole $\left(10^{-4} \mathrm{M}\right)$, an inhibitor of $\mathrm{P}^{4} 50_{\mathrm{C} 17}$, markedly inhibited the spontaneous formation of $\mathrm{P}$ and $17 \mathrm{OH}-\Delta^{5} \mathrm{P}$ and totally suppressed the stimulatory effect of VT and MT on P and $17 \mathrm{OH}-\Delta^{5} \mathrm{P}$ biosynthesis (Fig. 8). 
Table 2. Specificity control of the vasotocin/mesotocin immunostaining

\begin{tabular}{lllllll}
\hline Doses/Peptides & Control & $10^{-10} \mathrm{M}$ & $10^{-9} \mathrm{M}$ & $10^{-8} \mathrm{M}$ & $10^{-7} \mathrm{M}$ \\
\hline VT & ++++ & ++ & ++ & + & - \\
MT & ++++ & +++ & +++ & ++ & - \\
\hline
\end{tabular}

Density of VT/MT immunostaining after incubation of frog brain sections with the monoclonal VP antibody (diluted 1:1000) or with the antibody preincubated with graded concentrations of synthetic VT or MT. The results are expressed as percentages of the intensity of the immunolabeling (IL) in the absence of peptide (positive control) and classified as follows:,$++++ 100 \%>\mathrm{IL} \geq 80 \% ;+++, 80 \%>\mathrm{IL} \geq 60 \%$;,$++ 60 \%>\mathrm{IL} \geq 40 \% ;+, 40 \%>\mathrm{IL} \geq 10 \%$; ,$- \mathrm{IL}<10 \%$.
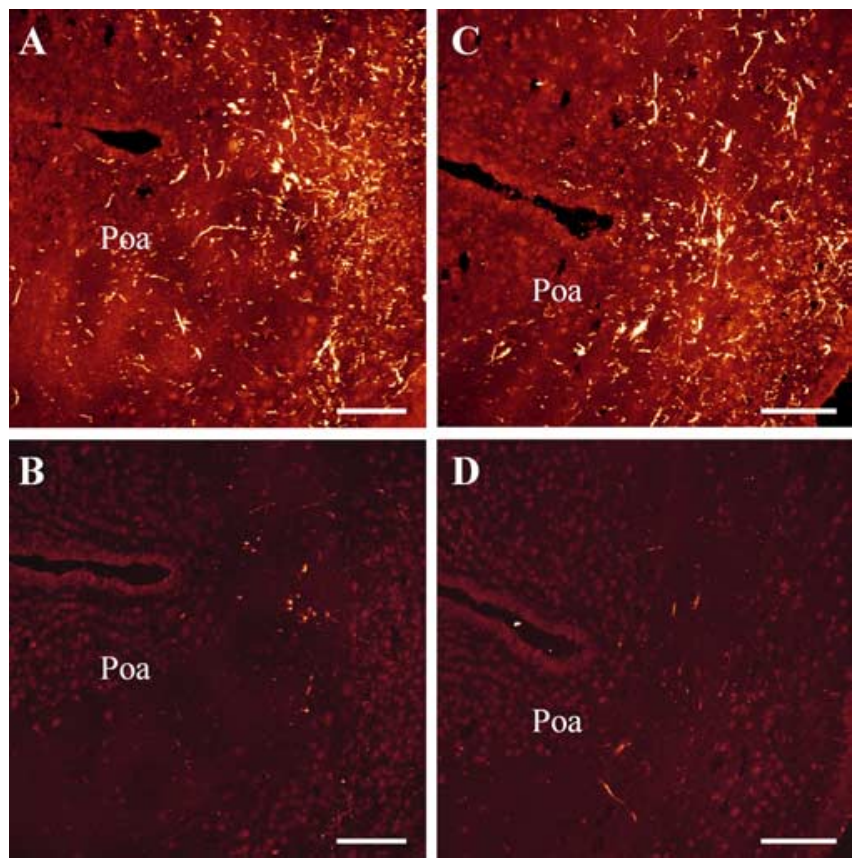

Figure 3. Labeling of consecutive frontal sections through the anterior preoptic area (Poa) showing the specificity control of the immunoreaction. Adjacent sections were incubated with the VP antibody $(A, C)$ or with the antibody preincubated with $10^{-7}$ M synthetic VT $(B)$ or $10^{-5}$ M MT (D). Scale bars, $100 \mu \mathrm{m}$.

\section{Pharmacological characterization of the receptor mediating the actions of VT and MT}

To determine the pharmacological profile of the receptors involved in the stimulatory actions of VT and MT, frog hypothalamic explants were incubated with various VP and OT receptor agonists and antagonists. Administration of the mutual VlaR/ V1bR agonist (1) [ $\left.\mathrm{Phe}^{2}, \mathrm{Orn}^{8}\right] \mathrm{OT}\left(10^{-7} \mathrm{M}\right)$ or the selective V1bR agonist (2) [deamino-Cys ${ }^{1}, \beta$-(3-pyridyl)-D- $\left.\mathrm{Ala}^{2}, \mathrm{Arg}^{8}\right] \mathrm{VP}$ $\left(10^{-7} \mathrm{M}\right)$ both mimicked the stimulatory effect of VT on the conversion of $\left[{ }^{3} \mathrm{H}\right] \Delta^{5} \mathrm{P}$ into $17 \mathrm{OH}-\Delta^{5} \mathrm{P}$ and $\mathrm{P}$ (Fig. 9). Conversely, the selective V2R agonist (3) [deamino-Cys ${ }^{1}, \mathrm{Val}^{4}$, D-Arg ${ }^{8}$ ] VP $\left(10^{-7} \mathrm{M}\right)$ did not significantly modify the formation of $17 \mathrm{OH}-\Delta^{5} \mathrm{P}$ and P by diencephalic explants (Fig. 9). The stimulatory effect of VT on the biosynthesis of $17 \mathrm{OH}-\Delta^{5} \mathrm{P}$ and $\mathrm{P}$ was completely suppressed by the selective V1aR antagonists (4) $\left[\mathrm{d}\left(\mathrm{CH}_{2}\right)_{5}{ }^{1}, \operatorname{Tyr}(\mathrm{Me})^{2}, \mathrm{Arg}^{8}\right] \mathrm{VP}\left(10^{-6} \mathrm{M}\right)$ and (5) [Phe-acetyl ${ }^{1}$, O-Me-D-Tyr $\left.{ }^{2}, \mathrm{Arg}^{6,8}, \mathrm{Lys}^{9}\right] \mathrm{VP}-\mathrm{NH}_{2}\left(10^{-6} \mathrm{M}\right)$ (Fig. 10). In contrast, the V2R antagonist (6) $\left[\mathrm{d}\left(\mathrm{CH}_{2}\right)_{5}{ }^{1}, \mathrm{D}-\mathrm{Ile}^{2}, \mathrm{Ile}^{4}, \mathrm{Arg}^{8}\right] \mathrm{VP}$ $\left(10^{-6} \mathrm{M}\right)$ and the OTR antagonist $(7)\left[\mathrm{d}\left(\mathrm{CH}_{2}\right)_{5}{ }^{1}, \mathrm{Tyr}(\mathrm{Me})^{2}\right.$, $\mathrm{Thr}^{4}, \mathrm{Orn}^{8}$, des-Gly- $\mathrm{NH}_{2}{ }^{9}$ ]VT $\left(10^{-6} \mathrm{M}\right)$ did not significantly affect VT-induced stimulation of $17 \mathrm{OH}-\Delta^{5} \mathrm{P}$ and $\mathrm{P}$ synthesis (Fig. 10). Concurrently, the stimulatory effect of MT on the production of $17 \mathrm{OH}-\Delta^{5} \mathrm{P}$ and $\mathrm{P}$ was not mimicked by the OTR agonist (8) $\left[\mathrm{Thr}^{4}\right.$, Gly ${ }^{7}$ OT $\left(10^{-7} \mathrm{M}\right)$ but was markedly reduced by both the selective VlaR antagonist (4) $\left[\mathrm{d}\left(\mathrm{CH}_{2}\right)_{5}{ }^{1}, \mathrm{Tyr}(\mathrm{Me})^{2}\right.$, $\operatorname{Arg}^{8}$ ]VP $\left(10^{-6} \mathrm{M}\right)$ and the specific OTR antagonist (7)
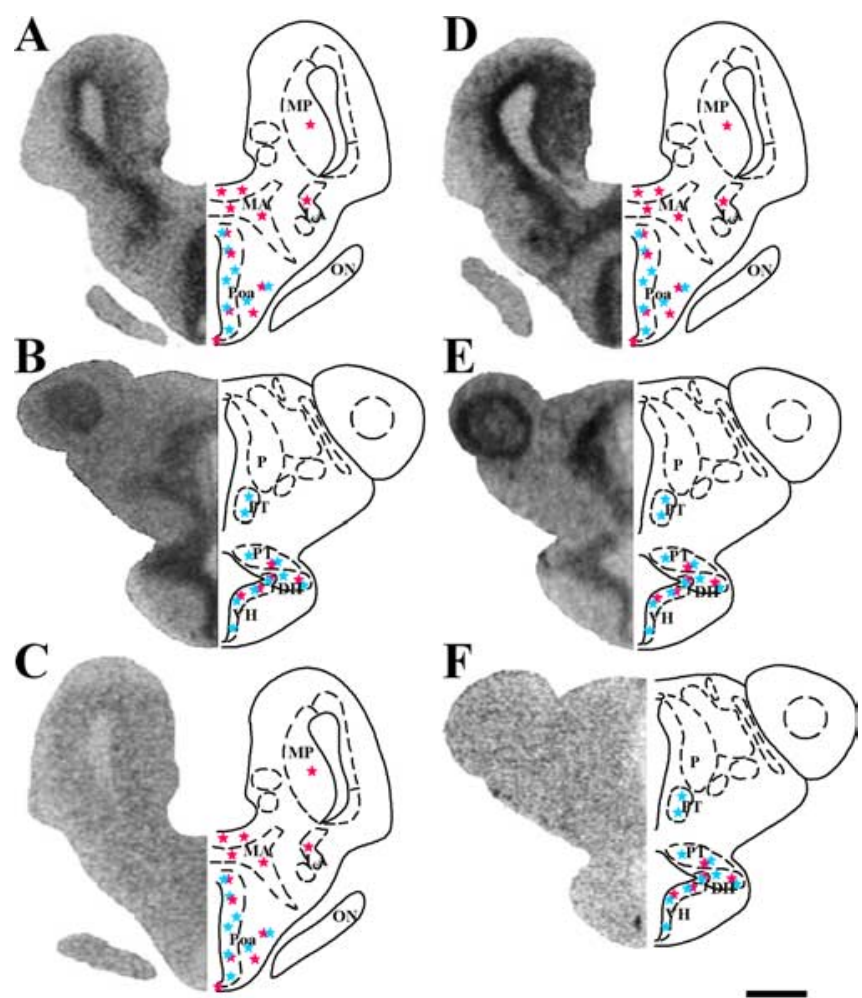

Figure 4. In situ hybridization analysis showing the distribution of VTR mRNA $(A-C)$ and MTR mRNA $(\boldsymbol{D}-\boldsymbol{F})$ in the frog diencephalon. Frontal brain sections were hybridized with the antisense VTR riboprobe $(\boldsymbol{A}, \boldsymbol{B})$ or the antisense MTR riboprobe $(\boldsymbol{D}, \boldsymbol{E})$. Consecutive sections to those shown in $\boldsymbol{A}$ and $\boldsymbol{E}$ were hybridized with the sense VTR riboprobe $(\boldsymbol{C})$ or the sense MTR riboprobe $(\boldsymbol{F})$. The anatomical distributions of $3 \beta$-HSD-positive cell bodies (blue asterisks) and

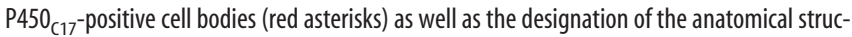
tures are indicated on the right hemisections. For abbreviations, see Table 1. Scale bar, $500 \mu \mathrm{m}$.

$\left[\mathrm{d}\left(\mathrm{CH}_{2}\right)_{5}{ }^{1}, \operatorname{Tyr}(\mathrm{Me})^{2}, \mathrm{Thr}^{4}, \mathrm{Orn}^{8}\right.$, des-Gly-NH$\left.{ }_{2}{ }^{9}\right] \mathrm{VT}\left(10^{-6} \mathrm{M}\right.$ each) (Fig. 11). Finally, MT-induced production of $17 \mathrm{OH}-\Delta^{5} \mathrm{P}$ and $\mathrm{P}$ was not affected by the specific V2R antagonist (6) $\left[\mathrm{d}\left(\mathrm{CH}_{2}\right)_{5}{ }^{1}, \mathrm{D}-\mathrm{Ile}^{2}, \mathrm{Ile}^{4}, \mathrm{Arg}^{8}\right] \mathrm{VP}\left(10^{-6} \mathrm{M}\right)$ (Fig. 11).

\section{Discussion}

Neurosteroids exert a large array of neurophysiological and behavioral activities, suggesting that the biosynthesis of steroids in the brain must be tightly controlled. However, to date, little is known regarding the neuronal mechanisms regulating the activity of neurosteroid-producing cells. The present study has shown that, in the frog diencephalon, neurons expressing the steroidogenic enzymes $3 \beta$-HSD and $\mathrm{P} 450_{\mathrm{C} 17}$ are contacted by VT/MTpositive fibers and that VT and MT stimulate the production of $\Delta^{4}$-3-keto- and $\Delta^{5}$-3 $\beta$-hydroxy-neurosteroids.

Anatomical relationship between neurosteroid-producing neurons, VTergic/MTergic fibers, and VT/MT receptors The neuronal populations containing $3 \beta$-HSD and VT/MT immunoreactivities have been mapped previously in the brain of the 

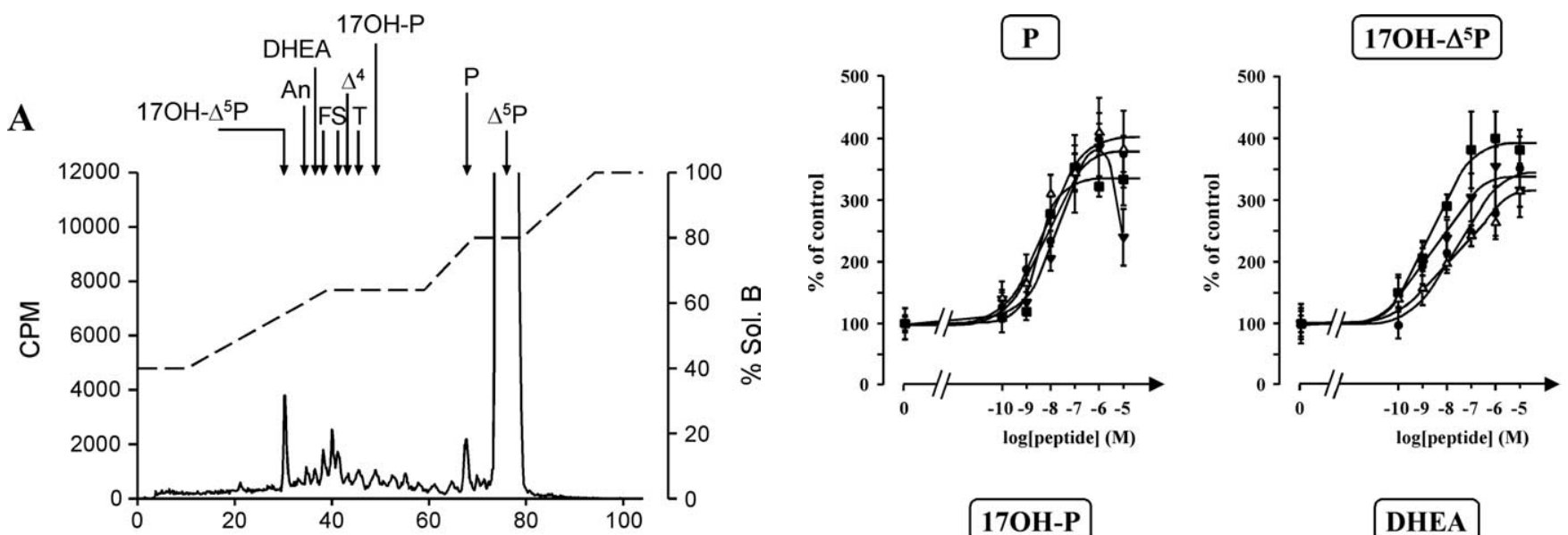

B
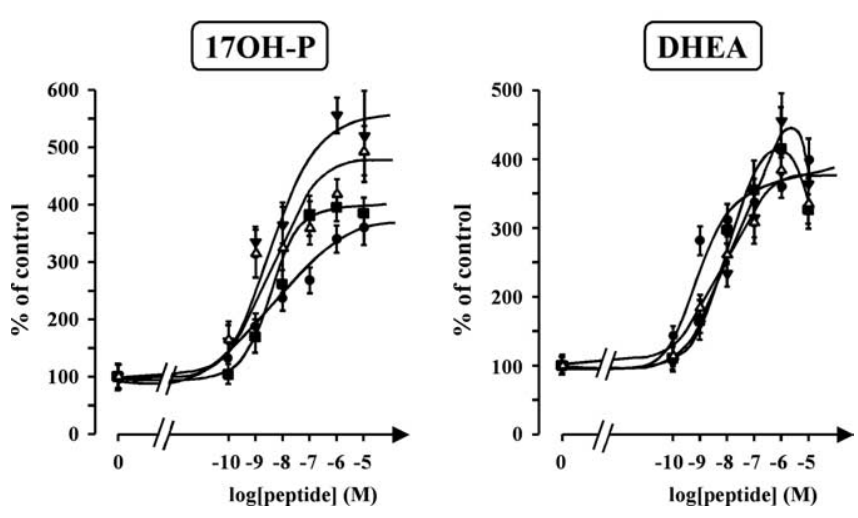

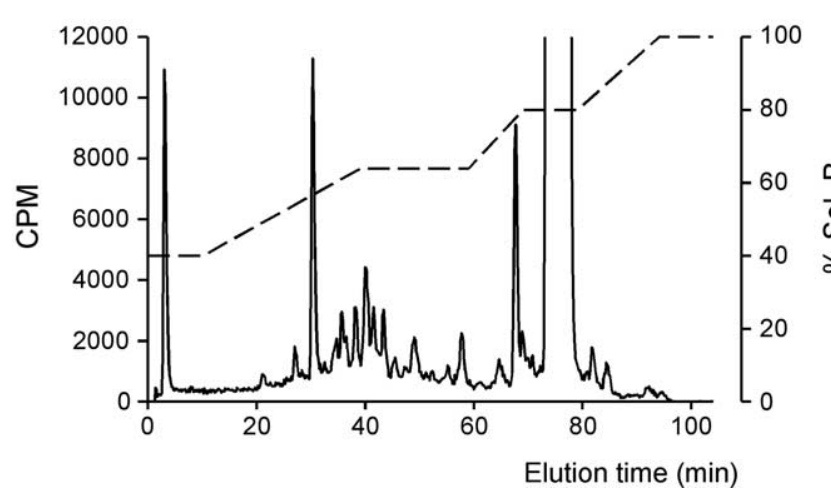

Figure 5. HPLC analysis of radioactive steroids extracted from frog hypothalamic explants after a $2 \mathrm{~h}$ incubation with $\left[{ }^{3} \mathrm{H}\right] \Delta^{5} \mathrm{P}$ in control conditions $(\boldsymbol{A})$ or in the presence of $10^{-7} \mathrm{MVT}$ $(\boldsymbol{B})$. The ordinate axis indicates the radioactivity measured in the HPLC eluent. The dashed lines represent the gradient of secondary solvent (percentage solution B). The arrows indicate the elution positions of standard steroids.

European green frog R. esculenta/ridibunda (González and Smeets, 1992; Mensah-Nyagan et al., 1994; Smeets and González, 2001). A comparison of these two neuronal systems has revealed that the diencephalic nuclei containing $3 \beta$-HSD-expressing neurons also exhibit a high density of VT/MT-positive fibers and terminals (Table 1). Likewise, the magnocellular preoptic nucleus, which contains a population of $\mathrm{P} 40_{\mathrm{C} 17}$-expressing neurons, is innervated by VTergic/MTergic fibers (Table 1). Using a monoclonal antibody against VP (Robert et al., 1985) that has high affinity for VT and cross-reacts to a certain extent with MT, we now show that VT- and possibly MT-immunoreactive fibers are found in the close proximity of neurons expressing $3 \beta-\mathrm{HSD}$ and $\mathrm{P}_{450} \mathrm{C}_{17}$. Interestingly, in the quail hypothalamus, aromatase-containing cell bodies, which are responsible for the production of neuroestrogens, are also innervated by VTergic fibers (Viglietti-Panzica et al., 1994; Balthazart et al., 1997).

We recently cloned a V1a-type VTR and the MTR in R. esculenta (Acharjee et al., 2004), so that we are now able to compare the distribution of the mRNAs encoding these two receptors with the localization of steroidogenic neurons in the frog diencephalon (Table 1). Intense expression of VTR and/or MTR mRNAs was seen in most hypothalamic nuclei that contain $3 \beta$-HSDand/or $\mathrm{P} 450_{\mathrm{C}_{17}}$-positive neurons. Together, these neuroanatomical data prompted us to investigate the possible effects of VT and MT on neurosteroid biosynthesis in frog.
Figure 6. Effects of graded concentrations of VT $(\mathbf{O}), \mathrm{MT}(\boldsymbol{\square}), \mathrm{VP}(\triangle)$, and $\mathrm{OT}(\boldsymbol{\nabla})$ on the conversion of tritiated pregnenolone into $\mathrm{P}, 170 \mathrm{H}-\Delta^{5} \mathrm{P}, 170 \mathrm{H}-\mathrm{P}$, and DHEA by frog hypothalamic explants. The values were calculated from the areas under the peaks in chromatograms similar to those presented in Figure 5. Results are expressed as percentages of the amount of each steroid formed in the absence of peptides. Values are the mean \pm SEM of four independent experiments.

\section{Effect of VT and MT on neurosteroid biosynthesis}

Using a pulse-chase approach, we show that VT and MT, as well as their mammalian counterparts VP and OT, induce a concentration-dependent stimulation of the formation of $\Delta^{4}-3$ keto-steroids, including $\mathrm{P}$ and $17 \mathrm{OH}-\mathrm{P}$, and $\Delta^{5}-3 \beta$ hydroxysteroids, including $17 \mathrm{OH}-\Delta^{5} \mathrm{P}$ and DHEA. The stimulatory effect of $\mathrm{VT}$ and MT on $\mathrm{P}$ and $17 \mathrm{OH}-\Delta^{5} \mathrm{P}$ production was suppressed by the $3 \beta$-HSD inhibitor trilostane and the $\mathrm{P} 450_{\mathrm{C} 17}$ inhibitor ketoconazole. These data provide the first evidence that peptides of the VP family activate neural cells that express $3 \beta$ $\mathrm{HSD}$ and $\mathrm{P} 40_{\mathrm{C} 17}$. Worthy of note, it has been shown previously that VP-related peptides can regulate the activity of peripheral steroidogenic organs; in particular, the secretion of corticosteroids is stimulated by VP in rat and human (Hinson et al., 1987; Perraudin et al., 1993; Guillon et al., 1995) and by VT in frog (Larcher et al., 1989).

Time course experiments revealed that a 30 min incubation of hypothalamic explants with VT or MT was sufficient to induce a robust increase in neurosteroid production and that the maximum effect was observed after a $2 \mathrm{~h}$ exposure to VT or MT. This rapid response strongly suggests that VT and MT activate steroidogenic enzymes at a posttranslational level, possibly through serine (Ser) and/or threonine (Thr) phosphorylation. Consistent with this notion, it is now established that phosphorylation of Ser ${ }^{106}$ and $\mathrm{Thr}^{112}$ residues in human $\mathrm{P}_{450} \mathrm{C}_{17}$ stimulates the activity of the enzyme (Lin et al., 1993; Zhang et al., 1995; Miller et al., 1997; Pandey and Miller, 2005). Rapid changes in the activity of steroidogenic enzymes in nervous tissue has been reported 

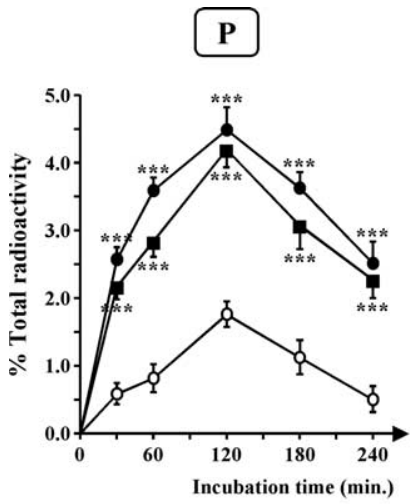

\section{H-P}

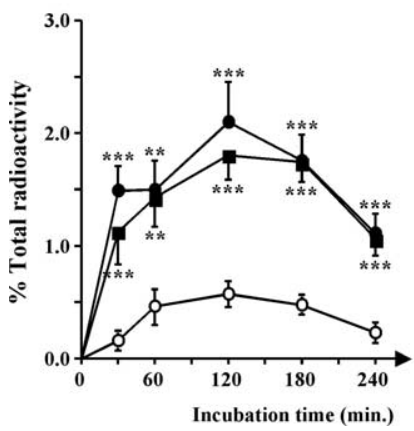

$170 H-\Delta^{5} \mathrm{P}$

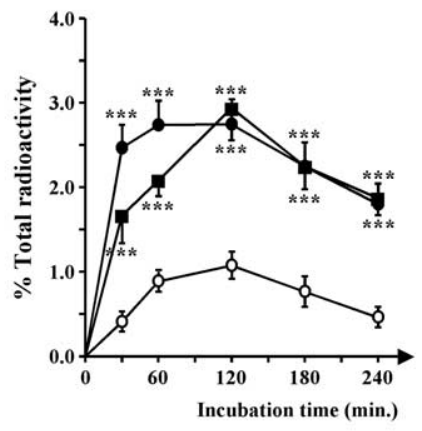

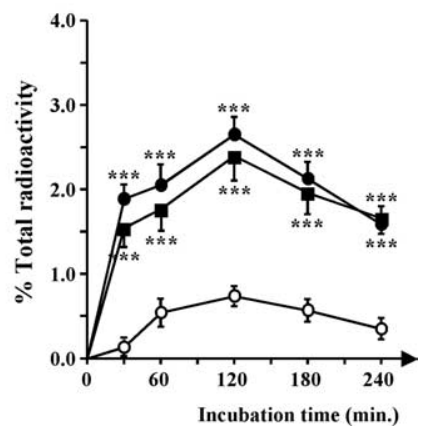

Figure 7. Time course of the conversion of $\left[{ }^{3} \mathrm{H}\right] \Delta^{5} \mathrm{P}$ into radioactive $\mathrm{P}, 170 \mathrm{H}-\Delta^{5} \mathrm{P}, 170 \mathrm{H}-\mathrm{P}$, and DHEA by frog hypothalamic explants in the absence $(\bigcirc)$ or presence $(0)$ of $10^{-7} \mathrm{M}$ vasotocin or $10^{-7} \mathrm{M}$ mesotocin $(\square)$. The values were calculated from the areas under the peaks in chromatograms similar to those presented in Figure 5. Results are expressed as percentages of the amount of each steroid formed compared with the total amount of radiolabeled compounds resolved by $H P L C$ analysis, including $\left[{ }^{3} \mathrm{H}\right] \Delta^{5}$ P. Values are the mean $\pm S E M$ of four independent experiments. ${ }^{* *} p<0.01$; ${ }^{* * *} p<0.001$ compared with respective control values (one-way ANOVA followed by a post hoc Dunnett's test).

previously. In particular, kainate, AMPA, and dopaminergic agonists have been shown to induce modifications of aromatase activity within minutes in quail hypothalamic explants (Balthazart et al., 2002, 2006). Similarly, a 30 min exposure of isolated rat retina to NMDA stimulates the production of $\Delta^{5} \mathrm{P}$ and $\Delta^{5} \mathrm{PS}$ (Guarneri et al., 1998). In vivo treatment of rat with the dopamine $\mathrm{D}_{4}$ antagonist clozapine induces a rapid increase in the concentration of $\mathrm{P}$, tetrahydroprogesterone, and tetrahydrodeoxycorticosterone in the cerebral cortex and striatum (Barbaccia et al., 2001). These observations, together with the present findings, are consistent with a posttranslational regulation of brain steroidogenic enzymes by neurotransmitters and neuropeptides. We cannot exclude, however, that VT and MT could also activate the expression of $3 \beta$-HSD and/or $\mathrm{P}_{450_{\mathrm{C} 17}}$ genes because a stimulatory effect was still observed $4 \mathrm{~h}$ after the onset of incubation with each of these peptides.

To investigate the possible interference of endogenous $\Delta^{5} \mathrm{P}$ in the conversion of $\left[{ }^{3} \mathrm{H}\right] \Delta^{5} \mathrm{P}$ into tritiated neurosteroids, pulsechase experiments were also performed in the presence of aminoglutethimide, a specific inhibitor of the cholesterol side-chain cleavage enzyme P450scc. The fact that aminoglutethimide did not affect the basal production of $\mathrm{P}$ and $17 \mathrm{OH}-\Delta^{5} \mathrm{P}$ indicates that the stimulatory effect of VT and MT cannot be accounted for by blockage of $\mathrm{P}$ biosynthesis. However, we found that aminoglutethimide slightly enhanced the stimulatory effect of VT and MT on $\mathrm{P}$ production, suggesting that endogenous $\Delta^{5} \mathrm{P}$ may compete

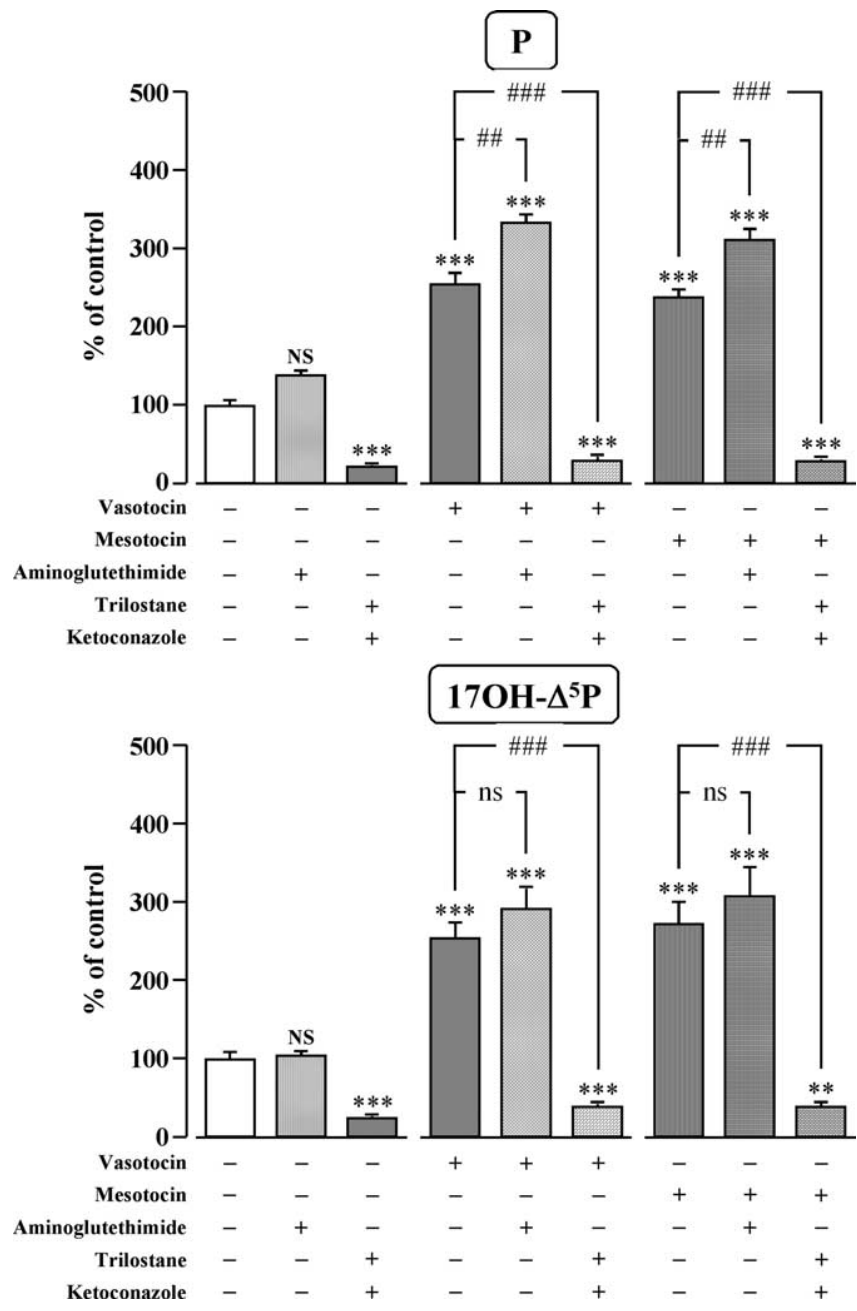

Figure 8. Effects of VT $\left(10^{-7} \mathrm{M}\right)$ and $\mathrm{MT}\left(10^{-7} \mathrm{M}\right)$ in the absence or presence of the cytochrome P450scc inhibitor aminoglutethimide $\left(10^{-4} \mathrm{M}\right)$, and the $3 \beta$-HSD inhibitor trilostane $\left(10^{-4} \mathrm{M}\right)$ and cytochrome $\mathrm{P}^{4} \mathrm{CO}_{\mathrm{C} 17}$ inhibitor ketoconazole $\left(10^{-4} \mathrm{M}\right)$ on the conversion of tritiated pregnenolone into $\mathrm{P}$ and $170 \mathrm{H}-\Delta^{5} \mathrm{P}$ by frog hypothalamic explants. The values were calculated from the areas under the peaks in chromatograms similar to those presented in Figure 5. Results are expressed as percentages of the amount of each steroid formed in the absence of drugs (control). Each value is the mean \pm SEM of four independent experiments. ${ }^{* * *} p<0.001$ versus control; ${ }^{\# \#} p<0.01,{ }^{\# \# \#} p<0.001$ versus VT- or MT-stimulated levels; NS, not statistically different from control; ns, not statistically different from VT- or MT-stimulated levels (one-way ANOVA followed by a post hoc Bonferroni's test).

with the tritiated precursor, leading to an attenuation of the steroidogenic response to $\mathrm{VT}$ and $\mathrm{MT}$.

\section{Pharmacological characterization of VT and MT receptors}

To determine the pharmacological profile of the receptors mediating the action of VT and MT on steroidogenic neurons, we used various peptidergic agonists and antagonists that have been developed for the study of mammalian VP/OT receptors (Manning and Sawyer, 1993). The stimulatory effect of VT was mimicked by the V1R agonist $\left[\mathrm{Phe}^{2}, \mathrm{Orn}^{8}\right.$ ] OT (Manning and Sawyer, 1984) and completely suppressed by the selective V1aR antagonists $\left[\mathrm{d}\left(\mathrm{CH}_{2}\right)_{5}{ }^{1}, \operatorname{Tyr}(\mathrm{Me})^{2}, \operatorname{Arg}^{8}\right] \mathrm{VP}$ (Kruszynski et al., 1980) and $\left[\right.$ Phe-acetyl ${ }^{1}, \mathrm{O}-\mathrm{Me}-\mathrm{D}-\mathrm{Tyr}^{2}, \mathrm{Arg}^{6,8}{ }^{6}$ Lys $\left.^{9}\right] \mathrm{VP}-\mathrm{NH}_{2}$ (Howl et al., 1993). In contrast, the $\mathrm{V} 2 \mathrm{R}$ agonist [deamino-Cys ${ }^{1}, \mathrm{Val}^{4}$, D-Arg ${ }^{8}$ ]VP (Manning and Sawyer, 1984), and the V2R antagonist $\left[\mathrm{d}\left(\mathrm{CH}_{2}\right)_{5}{ }^{1}, \mathrm{D}-\mathrm{Ile}^{2}, \mathrm{Ile}^{4}, \mathrm{Arg}^{8}\right] \mathrm{VP}$ (Manning et al., 1984) and the OTR antagonist $\left[\mathrm{d}\left(\mathrm{CH}_{2}\right)_{5}{ }^{1}\right.$, Tyr $(\mathrm{Me})^{2}, \mathrm{Thr}^{4}, \mathrm{Orn}^{8}$, des-Gly- 

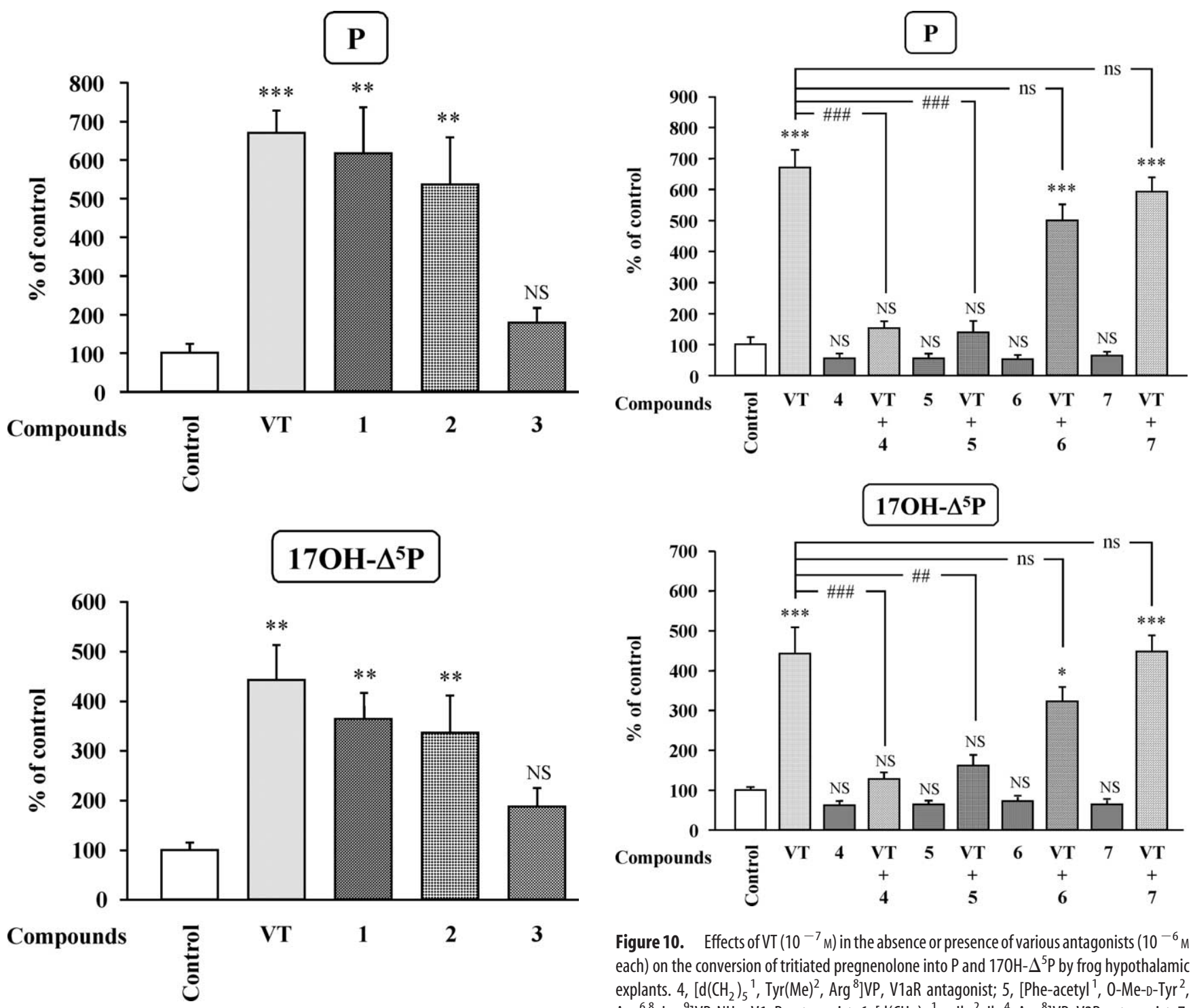

Figure 10. Effects of $\mathrm{VT}\left(10^{-7} \mathrm{M}\right)$ in the absence or presence of various antagonists $\left(10^{-6} \mathrm{M}\right.$ each) on the conversion of tritiated pregnenolone into $\mathrm{P}$ and $170 \mathrm{H}-\Delta^{5} \mathrm{P}$ by frog hypothalamic explants. 4, $\left[\mathrm{d}\left(\mathrm{CH}_{2}\right)_{5}{ }^{1}, \operatorname{Tyr}(\mathrm{Me})^{2}, \mathrm{Arg}^{8}\right] \mathrm{VP}, \mathrm{V} 1 \mathrm{aR}$ antagonist; 5, [Phe-acetyl ${ }^{1}, 0-\mathrm{Me}^{-D-}-\mathrm{Tyr}^{2}$, $\left.\mathrm{Arg}^{6,8}, \mathrm{Lys}^{9}\right] \mathrm{VP}-\mathrm{NH}_{2}, \mathrm{~V} 1 \mathrm{aR}$ antagonist; 6 , [d( $\left.\left(\mathrm{CH}_{2}\right)_{5}{ }^{1}, \mathrm{D}-\mathrm{Ile}^{2}, \mathrm{Ile}^{4}, \mathrm{Arg}^{8}\right] \mathrm{VP}, \mathrm{V} 2 \mathrm{R}$ antagonist; 7 , $\left[\mathrm{d}\left(\mathrm{CH}_{2}\right)_{5}{ }^{1}, \mathrm{Tyr}(\mathrm{Me})^{2}, \mathrm{Thr}^{4}, \mathrm{Orn}^{8}\right.$, des-Gly-NH $\left.{ }_{2}{ }^{9}\right] \mathrm{VT}, 0 \mathrm{TR}$ antagonist. The values were calculated

Figure 9. Effects of VT and various agonists $\left(10^{-7} \mathrm{M}\right.$ each) on the conversion of tritiated pregnenolone into $\mathrm{P}$ and $170 \mathrm{H}-\Delta^{5} \mathrm{P}$ by frog hypothalamic explants. 1, [Phe ${ }^{2}, \mathrm{Orn}^{8}$ ]0T, V1aR/ V1bR agonist; 2, [deamino-Cys ${ }^{1}, \beta$-(3-pyridyl)-D-Ala ${ }^{2}$, Arg $^{8}$ ]VP, selective V1bR agonist; 3 , [deamino-Cys ${ }^{1}, \mathrm{Val}^{4}, \mathrm{D}-\mathrm{Arg}^{8}$ ]VP, V2R agonist. The values were calculated from the areas under the peaks in chromatograms similar to those presented in Figure 5. Results are expressed as percentages of the amount of each steroid formed in the absence of peptide (control). Values are the mean \pm SEM of four independent experiments. ${ }^{* *} p<0.01$; ${ }^{* * *} p<0.001$; NS, not statistically different from control (one-way ANOVA followed by a post hoc Dunnett's test).

$\mathrm{NH}_{2}{ }^{9}$ ]VT (Manning and Sawyer, 1989) did not affect, respectively, spontaneous and VT-induced neurosteroid production. These observations, together with the expression of V1aR mRNA in the hypothalamic nuclei containing $3 \beta-\mathrm{HSD} / \mathrm{P}_{450} \mathrm{Cl}^{-}$ immunoreactive neurons strongly suggest that the effect of VT on neurosteroid biosynthesis is mediated through a V1a-like receptor. Conversely, the stimulatory effect of MT was blocked by the OTR antagonist $\left[\mathrm{d}\left(\mathrm{CH}_{2}\right)_{5}{ }^{1}\right.$, Tyr $(\mathrm{Me})^{2}, \mathrm{Thr}^{4}, \mathrm{Orn}^{8}$, des-Gly$\left.\mathrm{NH}_{2}{ }^{9}\right] \mathrm{VT}$, but the VlaR antagonist $\left[\mathrm{d}\left(\mathrm{CH}_{2}\right)_{5}{ }^{1}, \operatorname{Tyr}(\mathrm{Me})^{2}\right.$, $\mathrm{Arg}^{8}$ ]VP also blocked the response, and the OTR agonist [ $\mathrm{Thr}^{4}$, Gly $^{7}$ ]OT (Richard et al., 1991) was inactive. However, the fact that MT is $\sim 30$ times more potent on MTR-transfected cells than on VT1R- or V1aR-transfected cells (Acharjee et al., 2004) supports the notion that the effect of MT on neurosteroidogenesis is actually mediated through MTR. Furthermore, the V1b agonist from the areas under the peaks in chromatograms similar to those presented in Figure 5. Results are expressed as percentages of the amount of each steroid formed in the absence of peptide (control). Values are the mean \pm SEM of four independent experiments. ${ }^{*} p<0.05$, ${ }^{* * *} p<$ 0.001 versus control; $\#<0.01,{ }^{\# \#} p<0.001$ versus VT-stimulated levels; NS, not statistically different from control; $n$, not statistically different from VT-stimulated levels (one-way ANOVA followed by a post hoc Bonferroni's test).

[deamino-Cys ${ }^{1}, \beta$-(3-pyridyl)-D-Ala ${ }^{2}$, Arg $^{8}$ ]VP (Schwartz et al., 1991) provoked a significant stimulation of neurosteroid formation. Whether this effect should be ascribed to nonselective activation of the frog V1aR or to selective interaction with a V1bR remains to be determined. These data illustrate the limitation of using selective ligands designed for mammalian receptors to characterize the homologous receptors in nonmammalian species.

\section{Functional significance}

A number of studies have shown that central or peripheral injections of VT have profound effects on reproductive behaviors in amphibians (for review, see Moore et al., 1994; Iwata et al., 2000; Woolley et al., 2004). In particular, VT stimulates vocalization in green treefrogs (Penna et al., 1992), bullfrogs (Boyd, 1994), cricket frogs (Marler et al., 1995; Chu et al., 1998), great plain 

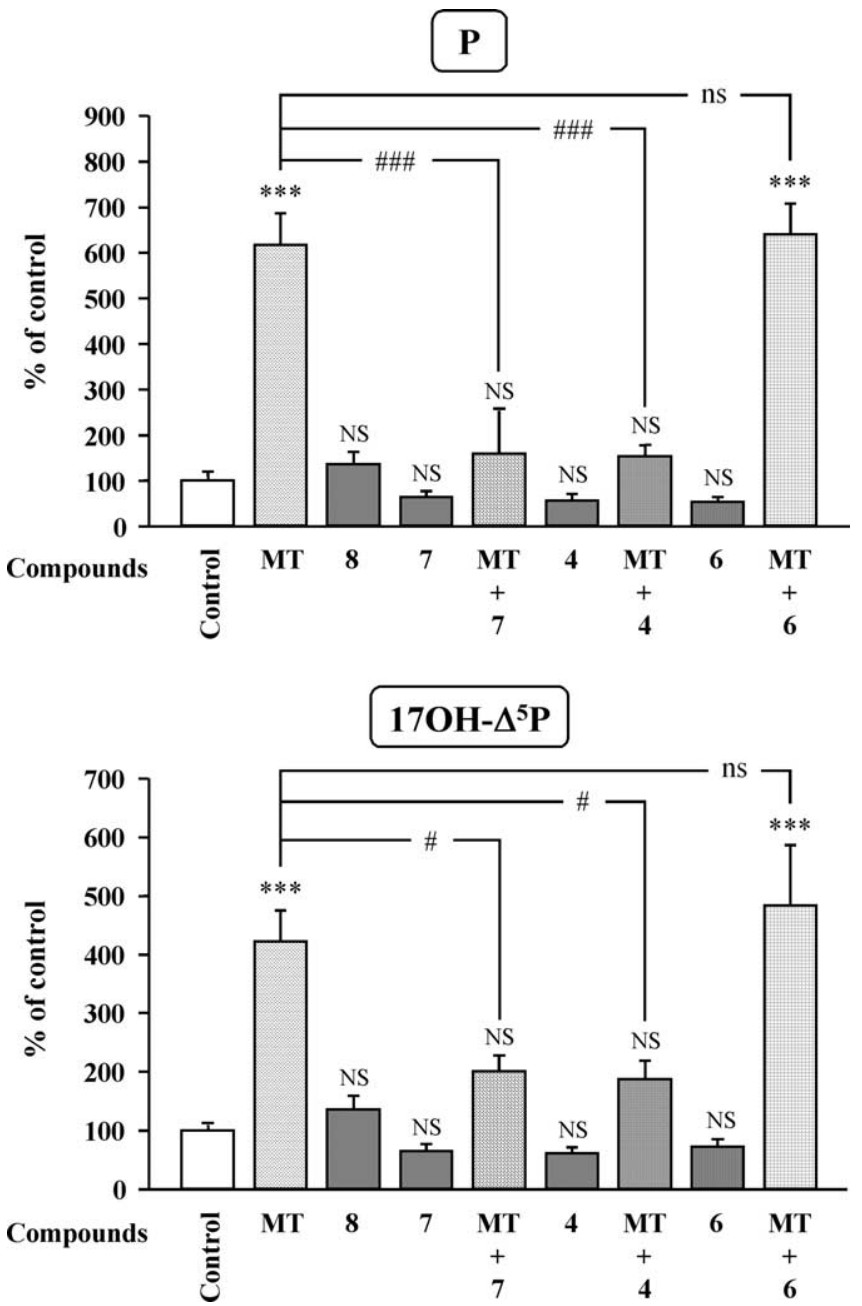

Figure 11. Effects of $\mathrm{MT}\left(10^{-7} \mathrm{M}\right)$ in the absence or presence of various antagonists $\left(10^{-6}\right.$ $\mathrm{M}$ each) and an OTR agonist $\left(10^{-7} \mathrm{M}\right)$ on the conversion of tritiated pregnenolone into $\mathrm{P}$ and $170 \mathrm{H}-\Delta^{5} \mathrm{P}$ by frog hypothalamic explants. $4,\left[\mathrm{~d}\left(\mathrm{CH}_{2}\right)_{5}{ }^{1}, \mathrm{Tyr}(\mathrm{Me})^{2}, \mathrm{Arg}^{8}\right] \mathrm{VP}, \mathrm{V} 1 \mathrm{aR}$ antagonist; 6, [d( $\left.\left(\mathrm{CH}_{2}\right)_{5}{ }^{1}, \mathrm{D}-\mathrm{Hle} \mathrm{e}^{2}, \mathrm{Hle}{ }^{4}, \mathrm{Arg}^{8}\right] \mathrm{VP}, \mathrm{V} 2 \mathrm{R}$ antagonist; $7,\left[\mathrm{~d}\left(\mathrm{CH}_{2}\right)_{5}{ }^{1}, \mathrm{Tyr}(\mathrm{Me})^{2}, \mathrm{Thr}^{4}, \mathrm{Orn}{ }^{8}\right.$, des-Gly$\left.\mathrm{NH}_{2}{ }^{9}\right] \mathrm{VT}$, OTR antagonist; $8,\left[\mathrm{Thr}^{4}, \mathrm{Gly}^{7}\right]$ OT, OTR agonist. The values were calculated from the areas under the peaks in chromatograms similar to those presented in Figure 5 . Results are expressed as percentages of the amount of each steroid formed in the absence of peptide (control). Values are the mean \pm SEM of four independent experiments. ${ }^{* * *} p<0.001$ versus control; $" \#<0.05$, \#\#\# $p<0.001$ vs MT-stimulated levels; NS, not statistically different from control; $n s$, not statistically different from MT-stimulated levels (one-way ANOVA followed by a post hoc Bonferroni's test).

toads (Propper and Dixon, 1997), and gray treefrogs (Semsar et al., 1998; Klomberg and Marler, 2000). Intracerebroventricular injection of VT also stimulates male courtship behavior, male amplectic behavior, and female sexual receptivity (Moore and Miller, 1983; Boyd, 1997; Klomberg and Marler, 2000; Thompson and Moore, 2000).

Concurrently, several reports indicate that neuroactive steroids regulate reproductive behaviors in amphibians (for review, see Moore et al., 2005). In particular, corticosterone inhibits mating and courtship behaviors (Moore and Miller, 1984), and testosterone facilitates clasping behavior (Moore and Rose, 2002) in male rough-skinned newts, and adrogens modulate vocalizations and advertisement callings in South African clawed frogs (Wetzel and Kelley, 1983; Kelley and Tobias, 1999). These observations together with the present findings strongly suggest that some of the behavioral effects of VP/VT and OT/MT could be mediated through modulation of neurosteroid-producing cell activity. In support of this hypothesis, several nuclei containing steroidogenic neurons in the frog telencephalon and diencephalon, including the lateral and medial amygdala, the anterior preoptic area, and the ventral hypothalamic nucleus are clearly involved in the regulation of male calling behavior (Boyd, 1997) and reproductive behavior (Zoeller and Moore, 1988; Moore et al., 2000) in amphibians.

In conclusion, the present study has provided the first evidence for neuroanatomical relationships between VTergic neurons and neurosteroid-secreting cells in the CNS of vertebrates. Our data demonstrate that VT and/or MT stimulate the biosynthesis of $\Delta^{4}$-3-keto-neurosteroids and $\Delta^{5}-3 \beta$-hydroxyneurosteroids, suggesting that some of the neurophysiological actions of VT and MT could be mediated through modulation of the activity of $3 \beta$-HSD- and $\mathrm{P} 450_{\mathrm{C} 17}$-expressing neurons.

\section{References}

Acharjee S, Do Rego JL, Oh DY, Ahn RS, Lee K, Vaudry H, Kwon HB, Seong JY (2004) Molecular cloning, pharmacological characterization, and histochemical distribution of frog vasotocin and mesotocin receptors. J Mol Endocrinol 33:293-313.

Akwa Y, Young J, Kabbadj K, Sancho MJ, Zucman D, Vourc'h C, Jung-Testas I, Hu ZY, Le Goascogne C, Jo DH, Corpéchot C, Simon P, Baulieu EE, Robel P (1991) Neurosteroids: biosynthesis, metabolism and function of pregnenolone and dehydroepiandrosterone in the brain. J Steroid Biochem Mol Biol 40:71-81.

Argiolas A, Gessa GL (1991) Central functions of oxytocin. Neurosci Biobehav Rev 15:217-231.

Balthazart J, Absil P, Viglietti-Panzica C, Panzica GC (1997) Vasotocinergic innervation of areas containing aromatase-immunoreactive cells in the quail forebrain. J Neurobiol 33:45-60.

Balthazart J, Baillien M, Ball GF (2002) Interactions between aromatase (estrogen synthase) and dopamine in the control of male sexual behavior in quail. Comp Biochem Physiol 132:37-55.

Balthazart J, Baillien M, Ball GF (2006) Rapid control of brain aromatase activity by glutamatergic inputs. Endocrinology 147:359-366.

Barbaccia ML, Affricano D, Purdy RH, Maciocco E, Spiga F, Biggio G (2001) Clozapine, but not haloperidol, increases brain concentrations of neuroactive steroids in the rat. Neuropsychopharmacology 25:489-497.

Baulieu EE, Robel P, Schumacher M (1999) Neurosteroids: a new regulatory function in the nervous system (Baulieu EE, Robel P, Schumacher M, eds). Totowa, NJ: Humana.

Beaujean D, Mensah-Nyagan AG, Do-Rego JL, Luu-The V, Pelletier G, Vaudry H (1999) Immunocytochemical localization and biological activity of hydroxysteroid sulfotransferase in the frog brain. J Neurochem 72:848-857.

Beaujean D, Do-Rego JL, Galas L, Mensah-Nyagan AG, Fredriksson R, Larhammar D, Fournier A, Luu-The V, Pelletier G, Vaudry H (2002) Neuropeptide $\mathrm{Y}$ inhibits the biosynthesis of sulfated neurosteroids in the hypothalamus through activation of Y1 receptors. Endocrinology 143:1950-1963.

Bernardi F, Pluchino N, Beglinomini S, Lenzi E, Palumbo M, Luisi M, Genazzani AR (2004) Disadaptive disorders in women: allopregnanolone, a sensitive steroid. Gynecol Endocrinol 19:344-353.

Boyd SK (1994) Arginine vasotocin facilitation of advertisement calling and call phonotaxis in bullfrogs. Horm Behav 28:232-240.

Boyd SK (1997) Brain vasotocin pathways and the control of sexual behaviors in the bullfrog. Brain Res Bull 44:345-350.

Chu J, Marler CA, Wilczynski W (1998) The effects of arginine vasotocin on the calling behavior of male cricket frogs in changing social contexts. Horm Behav 34:248-261.

Compagnone NA, Mellon SH (2000) Neurosteroids: biosynthesis and function of these novel neuromodulators. Front Neuroendocrinol 21:1-56.

De Wied D (1997) Neuropeptides in learning and memory. Behav Brain Res 83:83-90.

De Wied D, Diamant M, Fodor M (1993) Central nervous system effects of the neurohypophyseal hormones and related peptides. Front Neuroendocrinol 14:251-302.

Do Rego JL, Mensah-Nyagan AG, Beaujean D, Vaudry D, Sieghart W, Luu- 
The V, Pelletier G, Vaudry H (2000) GABA, acting through GABA $A_{A}$ receptors, inhibits biosynthesis of neurosteroids in the frog hypothalamus. Proc Natl Acad Sci USA 97:13925-13930.

Everts HGJ, Koolhaas JM (1997) Lateral septal vasopressin in rats: role in social object recognition? Brain Res 760:1-7.

Everts HGJ, Koolhaas JM (1999) Differential modulation of lateral septal vasopressin receptor blockade in spatial learning, social recognition, and anxiety-related behaviors in rats. Behav Brain Res 99:7-16.

González A, Smeets WJAJ (1992) Comparative analysis of the vasotocinergic and mesotocinergic cells and fibers in the brain of two amphibians, the anuran Rana ridibunda and the urodele Pleurodeles waltlii. J Comp Neurol 315:53-73.

Goodson JL, Bass AH (2001) Social behavior functions and related anatomical characteristics of vasotocin/vasopressin systems in vertebrates. Brain Res Rev 35:246-265.

Guarneri P, Russo D, Cascio C, De Leo G, Piccoli F, Guarneri R (1998) Induction of neurosteroid synthesis by NMDA receptors in isolated rat retina: a potential early event in excitotoxicity. Eur J Neurosci 10:1752-1763.

Guillon G, Trueba M, Joubert D, Grazzini E, Chouinard L, Côté M, Payet MD, Manzoni O, Barberis C, Robert M, Gallot-Payet N (1995) Vasopressin stimulates steroid secretion in human adrenal glands: comparison with angiotensin-II effect. Endocrinology 136:1285-1295.

Hinson JP, Vinson GP, Porter ID, Whitehouse BJ (1987) Oxytocin and arginine vasopressin stimulate steroid secretion by the isolated perfused rat adrenal gland. Neuropeptides 10:1-7.

Howl J, Wang X, Kirk CJ, Wheatley M (1993) Fluorescent and biotinylated linear peptides as selective bifunctional ligands for the Vla vasopressin receptor. Eur J Biochem 213:711-719.

Hugin-Flores ME, Steimer T, Schulz P, Valloton MB, Aubert ML (2003) Chronic corticotrophin-releasing hormone and vasopressin regulate corticosteroid receptors in rat hippocampus and anterior pituitary. Brain Res 976:159-170.

Iwata T, Toyoda F, Yamamoto K, Kikuyama S (2000) Hormonal control of urodele reproductive behavior. Comp Biochem Physiol B Biochem Mol Biol 126:221-229.

Kelley DG, Tobias ML (1999) The vocal repertoire of Xenopus laevis. The design of animal communication (Hauser M, Konishi M, eds), pp 9-35. Cambridge, MA: MIT.

Klomberg KF, Marler CA (2000) The neuropeptide arginine vasotocin alters male call characteristics involved in social interactions in the grey treefrog, Hyla versicolor. Anim Behav 59:807-812.

Kruszynski M, Lammek B, Manning M, Seto J, Haldar J, Sawyer WH (1980) [1-beta-Mercapto-beta,beta-cyclopentamethylenepropionic acid),2-(Omethyl)tyrosine] argine-vasopressin and [1-beta-mercapto-beta,betacyclopentamethylenepropionic acid)] argine-vasopressine, two highly potent antagonists of the vasopressor response to arginine-vasopressin. J Med Chem 23:364-368.

Larcher A, Delarue C, Idres S, Lefebvre H, Feuilloley M, Vandesande F, Pelletier G, Vaudry H (1989) Identification of VT-like immunoreactivity in chromaffin cells of the frog adrenal gland: effect of VT on corticosteroid secretion. Endocrinology 125:2691-2700.

Lin D, Black SM, Nagahama Y, Miller WL (1993) Steroid 17 $\alpha$-hydroxylase and 17,20-lyase activities of P450c17: Contributions of serine ${ }^{106}$ and P450 reductase. Endocrinology 132:2498-2506.

Luu-The V, Lachance Y, Labrie C, Leblanc G, Thomas JL, Strickler RC, Labrie F (1989) Full length cDNA structure and deduced amino acid sequence of human 3b-hydroxy-5-ene steroid dehydrogenase. Mol Endocrinol 3:1310-1312.

Manning M, Sawyer WH (1984) Design and uses of selective antagonistic analogs of the neuropeptides oxytocin and vasopressin. Trends Neurosci $7: 6-9$.

Manning M, Sawyer WH (1989) Discovery, development and some uses of vasopressin and oxytocin antagonists. J Lab Clin Med 114:617-632.

Manning M, Sawyer WH (1993) Design, synthesis and some uses of receptor-specific agonists and antagonists of vasopressin and oxytocin. Recept Res 13:195-214.

Manning M, Nawrocka E, Misicka A, Olma A, Klis WA, Seto J, Sawyer WH (1984) Potent and selective antagonists of the antidiuretic responses to arginine-vasopressin based on modifications of [1-(beta-mercaptobeta,beta-pentamethylenepropionic acid),2-d-isoleucine,4-valine]argininevasopressin at position 4. J Med Chem 27:423-429.
Marler CA, Chu J, Wilczynski W (1995) Arginine vasotocin injection increases probability of calling in cricket frogs, but causes call changes characteristic of less aggressive males. Horm Behav 29:554-570.

Mellon S, Vaudry H (2001) Biosynthesis of neurosteroids and regulation of their synthesis. Int Rev Neurobiol 46:33-78.

Mensah-Nyagan AG, Feuilloley M, Dupont E, Do-Rego JL, Leboulenger F, Pelletier G, Vaudry H (1994) Immunocytochemical localization and biological activity of $3 \beta$-hydroxysteroid dehydrogenase in the central nervous system of the frog. J Neurosci 14:7306-7318.

Mensah-Nyagan AG, Feuilloley M, Do-Rego JL, Marcual A, Lange C, Tonon MC, Pelletier G, Vaudry H (1996a) Localization of $17 \beta$-hydroxysteroid dehydrogenase and characterization of testosterone in the brain of the male frog. Proc Natl Acad Sci USA 93:1423-1428.

Mensah-Nyagan AG, Do-Rego JL, Feuilloley M, Marcual A, Lange C, Pelletier $\mathrm{G}$, Vaudry H (1996b) In vivo and in vitro evidence for the biosynthesis of testosterone in the telencephalon of the female frog. J Neurochem 67:413-422.

Miller WL, Auchus R, Geller DH (1997) The regulation of 17,20 lyase activity. Steroids 62:133-142.

Moore FL, Miller LJ (1983) Arginine vasotocin induces sexual behavior of newts by acting on cells in the brain. Peptides 4:97-102.

Moore FL, Miller LJ (1984) Stress-induced inhibition of sexual behavior: corticosterone inhibits courtship behaviors of a male amphibian (Taricha granulose). Horm Behav 18:400-410.

Moore FL, Rose JD (2002) Sensorimotor processing model: how vasotocin and corticosterone interact and control reproductive behaviors in an amphibian. Hormones, brain, and behavior, Vol 2 (Pfaff DW, Arnold AP, Etgen AM, Fahrbach SE, Rubin RT, eds), pp 515-545. San Diego: Academic.

Moore FL, Lowry CA, Rose JD (1994) Steroid-neuropeptide interactions that control reproductive behaviors in an amphibian. Psychoneuroendocrinology 19:581-592.

Moore FL, Richardson C, Lowry CA (2000) Sexual dimorphism in numbers of vasotocin-immunoreactive neurons in brain areas associated with reproductive behaviors in the roughskin newt. Gen Comp Endocrinol 117:281-298.

Moore FL, Boyd SK, Kelley DB (2005) Historical perspective: hormonal regulation of behaviors in amphibians. Horm Behav 48:373-383.

Neary TJ, Northcutt RG (1983) Nuclear organization of the bullfrog diencephalon. J Comp Neurol 213:262-278.

Pandey VA, Miller WL (2005) Regulation of 17,20 lyase activity by cytochrome $b_{5}$ and by serine phosphorylation of P450c17. J Biol Chem 280:13265-13271.

Patchev VK, Hassan AHS, Holsboer F, Almeida OFX (1996) The neurosteroid tetrahydroprogesterone attenuates the endocrine response to stress and exerts glucocorticoid-like effects on vasopressin gene transcription in the rat hypothalamus. Neuropsychopharmacology 15:533-540.

Penna M, Capranica RR, Somers J (1992) Hormone-induced vocal behavior and midbrain auditory sensitivity in the green treefrog, Hyla cinerea. J Comp Physiol 170:73-82.

Perraudin V, Delarue C, Lefevre H, Contesse V, Kuhn JM, Vaudry H (1993) Vasopressin stimulates cortisol secretion from human adrenocortical tissue through activation of V1 receptors. J Clin Endocrinol Metab 76:1522-1528.

Propper CR, Dixon TB (1997) Differential effects of arginine vasotocin and gonadotropin-releasing hormone on sexual behaviors in an anuran amphibian. Horm Behav 32:99-104.

Richard P, Moos F, Freund-Mercier MJ (1991) Central effects of oxytocin. Physiol Rev 71:331-370.

Robel P, Baulieu EE (1994) Neurosteroids: biosynthesis and function. Trends Endocrinol Metab 5:1-8.

Robert FR, Léon-Henri BP, Chapleur-Château MM, Girr MN, Burlet AJ (1985) Comparison of three immunoassays in the screening and characterization of monoclonal antibodies against arginine-vasopressin. J Neuroimmunol 9:205-220.

Rupprecht R, Holsboer F (1999) Neuroactive steroids: mechanisms of action and neuropsychopharmacological perspectives. Trends Neurosci 22:4704-4707.

Schwartz J, Derdowska I, Sobocinska M, Kupryszewski G (1991) A potent new synthetic analog of vasopressin with relative agonist specificity for pituitary. Endocrinology 129:1107-1109.

Semsar K, Klomberg KF, Marler C (1998) Arginine vasotocin increases 
calling-site acquisition by nonresident male grey treefrogs. Anim Behav 56:983-987.

Smeets WJAJ, González A (2001) Vasotocin and mesotocin in the brains of amphibians: state of the art. Microsc Res Tech 54:125-136.

Takase M, Ukena K, Yamazaki T, Kominami S, Tsutsui K (1999) Pregnenolone, pregnenolone sulfate, and cytochrome P450 side-chain cleavage enzyme in the amphibian brain and their seasonal changes. Endocrinology 140:1936-1944.

Thompson RR, Moore FL (2000) Vasotocin stimulates appetitive responses to the visual and pheromonal stimuli used by male roughskin newts during courtship. Horm Behav 38:75-85.

Thompson RR, Moore FL (2003) The effects of sex steroids and vasotocin on behavioral responses to visual and olfactory sexual stimuli in ovariectomized female roughskin newts. Horm Behav 44:311-318.

Tremblay Y, Fleury A, Beaudouin C, Vallee M, Belanger A (1994) Molecular cloning and expression of guinea pig cytochrome P450c17 cDNA (steroid 17 alpha-hydroxylase/17, 20 lyase): tissue distribution, regulation, and substrate specificity of the expressed enzyme. DNA Cell Biol 13:1199-1212.

Vallée M, Rivera JD, Koob GF, Purdy RH, Fitzgerald RF (2000) Quantification of neurosteroids in rat plasma and brain following swim stress and allopregnanolone administration using negative chemical ionization gas chromatography/mass spectrometry. Anal Biochem 287:153-166.

Vallée M, Mayo W, Le Moal M (2001) Role of pregnenolone, dehydroepiandrosterone and their sulfate esters on learning and memory in cognitive aging. Brain Res Rev 37:301-312.

Viglietti-Panzica C, Aste N, Balthazart J, Panzica GC (1994) Vasotocinergic innervation of sexually dimorphic medial preoptic nucleus of the male Japanese quail: influence of testosterone. Brain Res 657:171-184.

Wetzel DM, Kelley DB (1983) Androgen and gonadotropin effects on male mate calls in South African clawed frogs, Xenopus laevis. Horm Behav 17:388-404.

Woolley SC, Sakata JT, Crews D (2004) Evolutionary insights into the regulation of courtship behavior in male amphibians and reptiles. Physiol Behav 83:347-360.

Zhang LH, Rodriguez H, Ohno S, Miller WL (1995) Serine phosphorylation of human P450c17 increases 17,20-lyase activity: implications for adrenarche and the polycystic ovary syndrome. Proc Natl Acad Sci USA 92:10619-10623.

Zoeller RT, Moore FL (1988) Brain arginine vasotocin concentrations related to sexual behaviors and hydromineral balance in an amphibian. Horm Behav 22:66-75. 